Miriam T. Stark

\title{
Landscapes, Linkages, and Luminescence: First-Millennium CE Environmental and Social Change in Mainland Southeast Asia
}

\section{Introduction}

Profound social transformations took place across South and Southeast Asia during the early first millennium CE, incorporating new religious and philosophical ideologies across the Old World. Conventional Southeast Asian scholarship uses documentary sources and art history to explain the origins of first-millennium CE developments, when temple-based Brahmanic and Buddhist religions, international trade networks, and the region's earliest cities emerged. Archaeological research documents Southeast Asians' materialization of indigenous and South Asian ideas in their construction of politico-ritual places and goods that linked these landscapes into broader interactional landscapes from the mid- to late third to the early seventh centuries CE: the Gupta period in South Asia. Researchers have delved into contemporary developments west and northwest of the Gupta epicenter to understand pan-regional developments during the first millennium CE. Expanding our vision eastward to Southeast Asia, whose concurrent developments have conventionally been attributed to "Hindicization" or "Indianization," 2 also contextualizes the Gupta Age and offers insights on panregional developments during the first millennium CE. Brahmanic structures that housed Indic gods offer chronological anchors and define geographic limits of new ideologies; urban scale and settling along trade routes yield demographic insights, and artifact provenances define interactional space. Such information is essential to interrogating environmental history and material matters.

Understanding how Southeast Asians used a South Asian idiom to establish a regional identity through religious ideologies and ritual practice is the goal of this chapter. Archaeological techniques document the development of new economic,

\footnotetext{
1 See Jason Emmanual Neelis, Early Buddhist Transmission and Trade Networks: Mobility and Exchange within and Beyond the Northwestern Borderlands of South Asia (Leiden: Brill, 2011). 2 For recent engagements with these issues, see Pierre-Yves Manguin, "Introduction," in Early Interactions between South and Southeast Asia: Reflections on Cross-Cultural Exchange, eds. PierreYves Manguin, A. Mani, and Geoff Wade (Singapore: Institute of Southeast Asian Studies, 2011), xiii-xxxi.
}

Ә Open Access. () 2021 Miriam T. Stark, published by De Gruyter. (cc) BY-NC-ND This work is licensed under a Creative Commons Attribution-NonCommercial-NoDerivatives 4.0 International License.

https://doi.org/10.1515/9783110674088-008 
political, and social networks that linked Mekong Delta settlements into a single polity by the mid-first millennium CE. Scholars working across Southeast Asia now identify three phases in Southeast Asia's contact with South Asian polities. ${ }^{3}$ The earliest phase, from ca. 400 to 300/200 BCE, is signaled by selected South Asiaderived goods in archaeological sites. A second and intensified phase of interaction took place from ca. $200 \mathrm{BCE}$ to $300 \mathrm{CE}$, ${ }^{4}$ a period for which South Asia-derived archaeological artifacts have been recovered from Southeast Asian sites and for which third-century CE Chinese annals describe "more than a thousand Indian Brahmans" in the Southeast Asian Kingdom of Funan. ${ }^{5}$

It is in the third phase of ideological transmission, from ca. 300 to $600 \mathrm{CE}{ }^{6}$ in which formalized Indic architectural forms appear across much of the region's coasts and river valleys. Across the Lower Mekong Basin (and particularly in the Mekong Delta), aspiring Khmer elites used South Asian ideological systems to build religious and social landscapes that became the foundation for early urban centers. ${ }^{7}$ Built to house both Brahmanic and Buddhist statuary, these structures also introduced the region's first dated inscriptions on sandstone stelae. ${ }^{8}$

3 See Bérénice Bellina and Ian Glover, "The Archaeology of Early Contact with India and the Mediterranean World, from the Fourth Century BC to the Fourth Century AD," in Southeast Asia: From Prehistory to History, eds. Ian Glover and Peter Bellwood (New York: RoutledgeCurzon, 2004), 68-88.

4 Alison Kyra Carter, "The Production and Exchange of Glass and Stone Beads in Southeast Asia from 500 BCE to the Early Second Millennium CE: An Assessment of the Work of Peter Francis in Light of Recent Research," Archaeological Research in Asia 6 (2016): 23-24; Glover and Bellina 2011.

5 Paul Wheatley, The Golden Khersonese: Studies in the Historical Geography of the Malay Peninsula before A.D. 1500 (Kuala Lumpur: University of Malaya Press, 1961), 17.

6 Bellina and Glover, "The Archaeology of Early Contact with India and the Mediterranean World," 75-77; Carter, "The Production and Exchange of Glass and Stone Beads in Southeast Asia," 23; Cristina Cobo Castillo, Bérénice Bellina, and Dorian Q. Fuller, "Rice, Beans, and Trade Crops on the Early Maritime Silk Route in Southeast Asia," Antiquity 90 (2016): 1255-69.

7 Miriam T. Stark, "Inscribing Legitimacy and Building Power in the Mekong Delta," in Counternarratives and Macrohistories: New Agendas in Archaeology and Ancient History, ed. Geoffrey Emberling (New York: Cambridge University Press, 2015).

8 Nadine Dalsheimer and Pierre-Yves Manguin, "Viṣnu mitrés et réseaux marchands en Asie du Sud-Est: Nouvelles données archéologiques sur le Ier millénaire apr. J.-C.,” Bulletin de l'École française d'Extrême-Orient 85 (1998): 87-116; Paul Lavy, "As in Heaven, So on Earth: The Politics of Viṣnu, Śiva and Harihara Images in Preangkorian Khmer Civilisation,” Journal of Southeast Asian Studies 341 (2003): 21-39; Pierre-Yves Manguin, "Pan-Regional Responses to South Asian Inputs in Early Southeast Asia," in 50 Years of Archaeology in Southeast Asia: Essays in Honour of Ian Glover, eds. Bérénice Bellina, Elisabeth A. Bacus, Thomas O. Pryce, and Jan Wisseman Christie (Bangkok: River Books, 2010), 172; Miriam Stark, "Pre-Angkorian 
The kinds of connectivity linking fourth- and fifth-century CE South and Southeast Asia during this dramatically transformative period remain a matter of some debate. Goods and people - including artisans, Buddhist monastics, Brahmanic Vaiṣnavas, and Tamil traders - moved between these regions. ${ }^{9}$ How did the spread of these Indic ideologies, with their concomitant institutionalization of religious cults across the Indian subcontinent, extend its reach to Southeast Asia? Alongside these developments in the religious landscape, the physical terrain - major river valleys and some deltas of mainland and peninsular Southeast Asia - was similarly transformed. New economic, political, and social networks emerged as long-standing maritime trade networks moved new goods and ideas and expanded their geographic range. Similar developments, often with no more than a two-hundred-year lag behind South Asia, emerge in Southeast Asia. Particular objects and icons, like images of the Buddha, appear in both the Lower Mekong Basin and South Asia and reflect broader ideological trends associated with the Gupta period. ${ }^{10}$

Cultures in areas neighboring the Gupta world, like the Pyu, adopted Buddhism by the mid-first millennium $\mathrm{CE}^{11}{ }^{11}$ other areas followed in the next fifty to one

Settlement Trends in Cambodia's Mekong Delta and the Lower Mekong Archaeological Project.” Bulletin of the Indo-Pacific Prehistory Association 26 (2006): 98-109.

9 On the movement of artisans, see Bérénice Bellina, "Maritime Silk Roads' Ornament Industries: Socio-Political Practices and Cultural Transfer in the South China Sea," Cambridge Archaeological Joumal 24 (2014): 345-77; and Alison Kyra Carter, "Garnet Beads in Southeast Asia: Evidence for Local Production?" in Crossing Borders in Southeast Asian Archaeology. Selected Papers from the 13th International Conference of the European Association of Southeast Asian Archaeologists, vol. 1, edited by Dominik Bonatz, Andreas Reinecke, and Mai Lin Tjoa-Bonatz (Singapore: NUS, 2012), 296-306. On religious specialists, see J. G. de Casparis, "Palaeogeography as an Auxiliary Discipline in Research on Early South East Asia," in Early South East Asia: Essays in Archaeology, History, and Historical Geography, edited by R. B. Smith and William Watson (New York: Oxford University Press, 1979), 386-7; Pierre-Yves Manguin, "The Transmission of Vaișnavism across the Bay of Bengal: Trade Networks and State Formation in Early Historic Southeast Asia," in Early Global Interconnectivity across the Indian Ocean World, vol. 2, Exchange of Ideas, Religions, and Technologies, edited by Anglea Schottenhammer (Basingstoke, UK: Palgrave Macmillan, 2019), 51-68; Peter Skilling, "Buddhism and the Circulation of Ritual in Early Peninsular Southeast Asia," in Early Interactions between South and Southeast Asia: Reflections on Cross-Cultural Exchange, eds. Pierre-Yves Manguin, A. Mani, and Geoff Wade (Singapore: Institute for Southeast Asian Studies, 2011), 373. For Tamil merchant groups, see John Guy, "Tamil Merchants and the Hindu-Buddhist Diaspora in Early Southeast Asia," in Early Interactions between South and Southeast Asia, 243-62.

10 See Robert L. Brown, "Indian Art Transformed: The Earliest Sculptural Styles of Southeast Asia," in Indian Art and Archaeology, eds. Ellen M. Raven and Karel R. van Kooij (Leiden: Brill, 1992), 43.

11 Janice Stargardt, "From the Iron Age to Early Cities at Sri Ksetra and Beikthano, Myanmar," Journal of Southeast Asian Studies 47 (2016): 357. 
hundred years. For decades, historiographical interpretations of Southeast Asia's first millennium have generated a kind of "Gupta echo effect" that often reduces Southeast Asia to a foggy reflection of its western neighbor. Detailed chronometric work on sites and their architectural features is scarce in both regions. To date, the literature suggests that South Asian ritual architectural technologies began in the late centuries $\mathrm{BCE}$, but the Hindu temple emerged some centuries later. ${ }^{12}$ Scripts, art styles, and architectural traditions in first-millennium Southeast Asia, all demonstrably produced in the region, reflect varying influences from the South Asian continent and vary by geographic region across mainland Southeast Asia.

Archaeological research documents Southeast Asians' materialization of indigenous and South Asian ideas in their construction of the politico-ritual places and goods that linked these landscapes within broader interactional landscapes from the mid- to late third to the early seventh centuries CE. Brahmanic and Buddhist structures that housed Indic gods define the geographic limits of new ideologies. Archaeological and art-historical work has begun to place these features in time and space. Yet the work of archaeologists is inherently paradoxical: we study past behaviors that we cannot observe, and these behaviors preserve differentially in the archaeological record and through a variety of media. Organic materials like wood, used for homes, watercraft, and religious images, were ubiquitous in the first-millennium CE Mekong Delta; so were spices, resins, and textiles, used in daily and ritual practice. Yet these are nearly invisible in its archaeological record, leaving infrequent microscopic traces (e.g., pollen, starch, residues, carbonized flecks) that rarely survive the tropical climate.

Such methodological challenges are doubled in studying this transitional period when the earliest documentary records appear in the region. Few historians dare to tread on this period, and most archaeologists prefer the prehistoric or later historic periods for study. Yet mainland Southeast Asia's archaeological record is ideally suited for studying two organizational changes that transformed societies: (1) the shift to institutionalized religion and large-scale ritual practice (largely through the shift to temple-based practices); and (2) the adoption of standardized writing systems. These changes had profound implications for the structure of Southeast Asian leadership and settlement organization, producing (among other changes) the region's earliest urban settlements. This chapter expands our current understandings of the greater Gupta world by

12 See Himanshu Prabha Ray, "The Apsidal Shrine in Early Hinduism: Origins, Cultic Affiliation, Patronage," World Archaeology 36 (2004): 343-359; Michael Willis, "The Formation of Temple Ritual in the Gupta Period: pūjā and pañcamahāyajña,” in Prajñādhara: Essays on Asian Art, History, Epigraphy and Culture in Honour of Gouriswar Bhattacharya, eds. Arundhati Banerji and Gerd J. R. Mevissen (New Delhi: Kaveri Books, 2009), 66-88. 
looking eastward to Suvaṇnabhūmi and using a case study from the Lower Mekong Basin (Cambodia and environs). Increasing archaeological and arthistorical attention to first-millennium CE mainland Southeast Asia illustrates multiple independent developmental trajectories.

\section{Finding the "Gupta Age" in Southeast Asia}

Conventional Southeast Asian scholarship uses documentary sources and art history to explain the origins of first-millennium CE developments, when temple-based Brahmanic and Buddhist religions, international trade networks, and the region's earliest cities emerged. Recent archaeological and art-historical approaches in both regions now illustrate differences and possible synergies in how Southeast Asians constructed politico-ritual landscapes in dialogue with South Asia during this time of religious dynamism. ${ }^{13}$ South Asian members of the Buddhist sangha - both learned monks and nuns - were active during the Gupta period, and scholars suggest multidirectional relationships that linked Gupta India and Southeast Asia as well as discrete chronologies associated with different subregions of Southeast Asia. ${ }^{14}$

Several subregions in mainland Southeast Asia reflect Gupta Age developments, so my discussion begins by sketching out general parameters of Southeast/ South Asia interactions from ca. 200 BCE to 500 CE. This time period, variously known as the Iron or Late Age, ${ }^{15}$ early historic period, ${ }^{16}$ or protohistoric period, ${ }^{17}$ is associated with Southeast Asia's transition to history, if we accept the Western

13 See Manguin, "The Transmission of Vaiṣnavism across the Bay of Bengal," 62-63.

14 Neelis, Early Buddhist Transmission and Trade Networks, 32; Himanshu Prabha Ray, Archaeology and Buddhism in South Asia (Oxfordshire, UK: Taylor and Francis, 2017), 22; Skilling, "Buddhism and the Circulation of Ritual,” 372.

15 Carter, "Garnet Beads in Southeast Asia," and "Beads, Exchange Networks and Emerging Complexity: A Case Study from Cambodia and Thailand (500 BCE-CE 500)," Cambridge Archaeological Journal 25 (2015): 733-57; Stargardt, "From the Iron Age to Early Cities."

16 Miriam T. Stark, "The Transition to History in the Mekong Delta: A View from Cambodia," International Journal of Historical Archaeology 2 (1998): 175-204.

17 Bellina, "Maritime Silk Roads' Ornament Industries”; Chureekamol Onsuwan Eyre, "Social Variation and Dynamics in Metal Age and Protohistoric Central Thailand: A Regional Perspective," Asian Perspectives 49 (2011): 43-84; Piphal Heng, "Transition to the Pre-Angkorian Period (300-500 CE): Thala Borivat and A Regional Perspective,” Journal of Southeast Asian Studies 47 (2016): 484-505; Rona M. Ikehara-Quebral et al., "Biocultural Practices during the Transition to History at the Vat Komnou Cemetery, Angkor Borei, Cambodia," Asian Perspectives 56 (2017): 191-236; Manguin, “Introduction.” 
equation of "history" with literacy. ${ }^{18}$ The few first-millennium CE transnational studies come largely from art history ${ }^{19}$ and suggest that social and demographic developments across mainland Southeast Asia took separate but parallel, and occasionally overlapping, trajectories ${ }^{20}$ during the late Gupta/post-Gupta period. Major cultural traditions, defined by Chinese toponyms, are illustrated in the map as Figure 1.

Burma's/Myanmar's Pyu populations embraced urbanization and Buddhism in the early centuries CE. ${ }^{21}$ Developments in what is now central Thailand took place later, in concert with late and post-Gupta India, with the Buddhist-influenced Dvaravati "civilization." 22 The earliest urban centers and Indic iconography in the Lower Mekong Basin, and particularly in the Mekong Delta, emerged at nearly the same time as those in Burma, but took different forms. Collectively, the region's chronology can be divided into three periods that span this transitional period and extend to the Gupta period, as illustrated in Figure 2.

Intensified intraregional and interregional contact was one factor that contributed to these 200 BCE-to-500 CE transformations. We know that South Asians desired myriad goods that circulated within and between regions in mainland Southeast Asia, including marine-shell ornaments, glass and semiprecious stone beads, copper and tin ingots, marble, serpentine, salt, and other commodities, by

18 See Stephen A. Murphy and Miriam T. Stark, "Introduction: Transition from Late Prehistory to Early Historic Periods in Mainland Southeast Asia c. Early to Mid-First Millennium CE," Journal of Southeast Asian Studies 47 (2016): 333-40; Miriam T. Stark and S. Jane Allen, "The Transition to History in Southeast Asia: An Introduction," International Journal of Historical Archaeology 2 (1998): 163-75.

19 E.g., Charlotte Galloway, "Ways of Seeing a Pyu, Mon and Dvaravati Artistic Continuum," Bulletin of the Indo-Pacific Prehistory Association 30 (2010): 70-8; Nicolas Revire, "Dvāravatī and Zhenla in the Seventh to Eighth Centuries: A Transregional Ritual Complex," Journal of Southeast Asian Studies 47 (2016): 393-417.

20 Miriam Stark, "Early Mainland Southeast Asian Landscapes in the First Millennium AD." Annual Review of Anthropology 35 (2006): 407-32.

21 See Bob Hudson, "A Thousand Years before Bagan: Radiocarbon Dates and Myanmar's Ancient Pyu Cities," in Bagan and the World: Early Myanmar and its Global Connections, eds. Michael Aung-Thwing, John N. Miksic, and Geok Y. Goh (Singapore: ISEAS-Yusof Ishak Institute, 2018), 88-121; Janice Stargardt, The Ancient Pyu of Burma, vol. 1, Early Pyu Cities in a Man-Made Landscape (Cambridge: Publications on Ancient Civilizations in Southeast Asia; Singapore: Institute of Southeast Asian Studies, 1990) and "From the Iron Age to Early Cities"; this volume.

22 See Ian Glover, "The Dvaravati Gap - Linking Prehistory and History in Early Thailand," Bulletin of the Indo-Pacific Prehistory Association 30 (2010): 79-86; Phasook Indrawooth, "The Archaeology of the Early Buddhist Kingdoms of Thailand," in Southeast Asia: From Prehistory to History, eds. Ian Glover and Peter Bellwood (New York: RoutledgeCurzon, 2004), 120-148. 


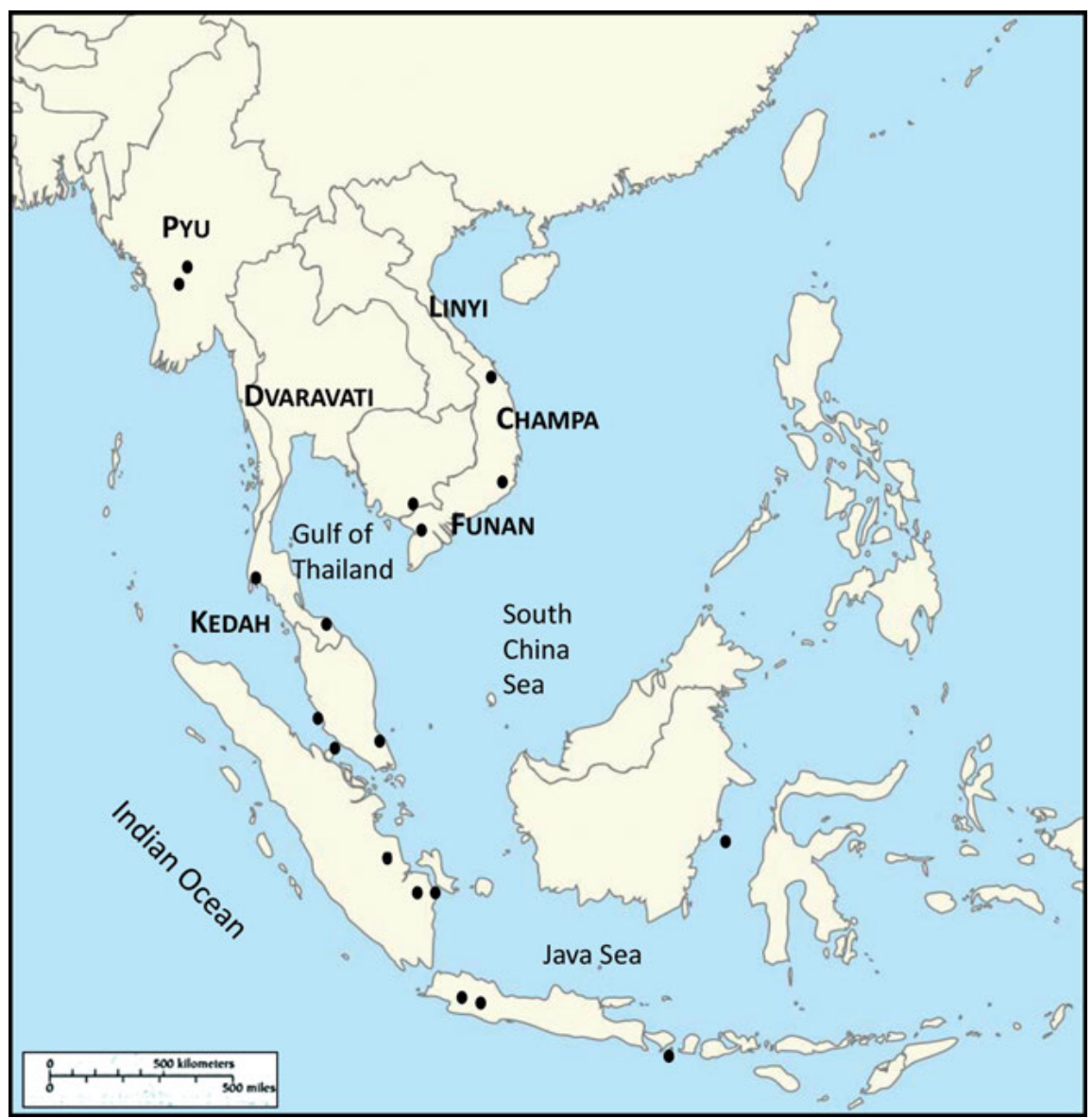

Figure 1: Major cultural traditions in first millennium Southeast Asia using Chinese toponyms, with some major sites indicated using black dots (using base map from https://commons.wiki media.org/wiki/File:Southeast_Asia_location_map.svg).

the late first millennium $\mathrm{BC} \cdot{ }^{23}$ Regional interactional networks that moved prestige goods like semiprecious stone and glass beads and bangles, worked precious metals, and silver coins expanded as communities grew increasingly localized in their utilitarian artifact styles; ${ }^{24}$ metals and silver coinage apparently expanded. Along

23 Bellina and Glover, "The Archaeology of Early Contact with India and the Mediterranean World," 69.

24 Eyre, "Social Variation and Dynamics in Metal Age and Protohistoric Central Thailand"; Joyce C. White, "Incorporating Heterarchy into Theory on Socio-Political Development: The 


\begin{tabular}{|l|l|l|l|}
\hline & \multicolumn{1}{|c|}{ C. 200 BCE-300 CE } & \multicolumn{1}{|c|}{ C. 320-550 CE } & \multicolumn{1}{|c|}{ 550-?750 CE } \\
\hline $\begin{array}{l}\text { Mainland } \\
\text { Southeast Asia }\end{array}$ & $\begin{array}{l}\text { Protohistoric } \\
\text { period/Late Iron Age }\end{array}$ & $\begin{array}{l}\text { Protohistoric-pre- } \\
\text { Angkorian } \\
\text { proto-Dvaravati }\end{array}$ & $\begin{array}{l}\text { Pre-Angkorian } \\
\text { Dvaravati } \\
\text { Pyu }\end{array}$ \\
& $\begin{array}{l}\text { Pyu } \\
\text { Cham }\end{array}$ & Cham \\
\hline $\begin{array}{l}\text { South Asia } \\
\text { (broadly glossed) }\end{array}$ & Early Historic Period & Gupta & Post-Gupta \\
\hline
\end{tabular}

Figure 2: Southeast Asian and South Asian chronologies from the late first millennium BCE to the $8^{\text {th }}$ century CE.

the coasts of the South China Sea, certain artifacts, like Indo-Roman rouletted ware, spouted vessels known as kendi, and glass beads appeared by the early centuries CE. The technological similarities of these objects suggest the development of pan-regional cultural and technological traditions. ${ }^{25}$ This timing coincides closely with the economic integration of India's entire east coast, involving the movement of pearls, gems, semiprecious stones, and perhaps even horses. ${ }^{26}$

Coastal emporiums in both regions held goods that the other desired; art historians and archaeologists ${ }^{27}$ support Chinese documentary sources suggesting that South Asian Brahmans lived in Southeast Asian communities by the third century CE. Whether or not they were long-term residents, South Asians

Case from Southeast Asia," in Heterarchy and the Analysis of Complex Societies, Archeological Papers of the American Anthropological Association 6, eds. Robert M. Ehrenreich, Carole L. Crumley, and Janet E. Levy (Arlington, VA: American Anthropological Association, 1995), 101-123.

25 E.g., Jan Wisseman Christie, "State Formation in Early Maritime Southeast Asia: A Consideration of the Theories and the Data," Bijdragen tot de Taal-, Land- en Volkenkunde 151 (1995): 235-88; Laure Dussubieux and Bérénice Bellina, "Glass Ornament Production and Trade Polities in the Upper-Thai Peninsula during the Early Iron Age," Archaeological Research in Asia 13 (2018): 25-36.

26 Himanshu Prabha Ray, "Early Maritime Contacts between South and Southeast Asia," Journal of Southeast Asian Studies 20 (1989): 43-46.

27 E.g., Guy, "Tamil Merchants and the Hindu-Buddhist Diaspora"; Skilling, "Buddhism and the Circulation of Ritual," 373; Bérénice Bellina-Pryce and Praon Silapanth, "Khao Sam Kaeo and the Upper Thai Peninsula: Understanding the Mechanisms of Early Trans-Asiatic Trade and Cultural Exchange," in Uncovering Southeast Asia's Past: Selected Papers from the 10th International Conference of the European Association of Southeast Asian Archaeologists, eds. Elisabeth A. Bacus, Ian C. Glover, and Vincent C. Pigott (Singapore: NUS Press, 2006), 390. 
came to Southeast Asia for its forest products and Chinese goods, in part through private entrepreneurial ventures whose profits were invested into Buddhist and Jaina monastic establishments along coastal eastern India by the second century BCE. $^{28}$ Southeast Asians, in turn, sought Indian punch-marked silver coins, ${ }^{29}$ beads made of glass, carnelian, and semiprecious stones, ${ }^{30}$ and perhaps also more perishable goods like cotton. ${ }^{31}$ Clear South Asian connections are evidenced by coinage derived from Southeast Asia's protohistoric sites: coins recovered from the Mekong Delta, for example, bear direct parallel to Chandravalli, Karnataka, and other areas in southern India. ${ }^{32}$ Populations at Sri Ksetra (Pyu) and Angkor Borei (Funan) first experimented with brick architectural technologies by the late centuries $\mathrm{BCE} .{ }^{33}$

Trade between South and Southeast Asia intensified after the Chinese emperor Han Wudi (r. ca. 140-87 BCE) established a "maritime silk route" from China to Rome via South Asia that operated into the Song and Yuan dynasties. Southern China's primary trading ports for this maritime silk route likely lay in Fujian and Guangdong provinces. Trade accelerated after Augustus established the Pax Romanica in 58 BCE, when Indian traders were finally permitted access to the Roman Empire (via the Red Sea) and thus to Mediterranean markets. ${ }^{34} \mathrm{By}$ the first century CE, Indian traders had reached the Malay Peninsula and, eventually, South China ports via Southeast Asia. And in the fourth and fifth centuries CE, maritime trade made regular use of the Malacca Straits and the South China Sea. Economic and political changes during mainland Southeast Asia's

28 Ray, "Early Maritime Contacts between South and Southeast Asia”; Himanshu Prabha Ray, The Winds of Change: Buddhism and the Maritime Links of Early South Asia (New Delhi: Oxford University Press, 1994).

29 R. S. Wicks, Money, Markets, and Trade in Early Southeast Asia: The Development of Indigenous Monetary Systems to AD 1400 (Ithaca, NY: Southeast Asia Program, Cornell University, 1992), 114-121, 156-164.

30 Carter, "Beads, Exchange Networks and Emerging Complexity" and "The Production and Exchange of Glass and Stone Beads in Southeast Asia"; James W. Lankton and and Laure Dussubieux, "Early Glass in Asian Maritime Trade: A Review and an Interpretation of Compositional Analyses,” Journal of Glass Studies 48 (2006): 121-44.

31 Judith Cameron, "Iron and Cloth Across the Bay of Bengal: New Data from Tha Kae, Central Thailand," Antiquity 85 (2011): 559-57.

32 Ray, "Early Maritime Contacts between South and Southeast Asia," 52; see also Wicks, Money, Markets, and Trade in Early Southeast Asia.

33 See Stargardt, "From the Iron Age to Early Cities," 348-351; Miriam T. Stark, David C. W. Sanderson, and Rob G. Bingham, "Monumentality in the Mekong Delta: Luminescence Dating and Implications," Bulletin of the Indo-Pacific Prehistory Association 26 (2006): 115-116.

34 Kenneth R. Hall, Maritime Trade and State Development in Early Southeast Asia (Sydney: George Allen \& Unwin, 1985), 28-29. 
protohistoric period reflect international factors, local developments, and longterm trends toward social stratification, ${ }^{35}$ all of which set the stage for the emergence of institutionalized religion and statecraft in the mid-first millennium CE.

Urbanization swept across Monsoon Asia from eastern India and the Bay of Bengal $^{36}$ to northern Vietnam by the first few centuries CE. ${ }^{37}$ Large population settlements emerged in inland regions that held high agrarian potential and along the South China Sea's coastline, ${ }^{38}$ whose deepwater ports and coastal settlements held valued export goods and housed foreign traders. Their populations managed, and perhaps in some cases restricted, ${ }^{39}$ the circulation of food, commodities, and exotic goods to inland settlements across the Lower Mekong Basin. Regional and extraregional trade was integral to their success. ${ }^{40}$ These trade networks had deeper roots into the late first millennium BCE, ${ }^{41}$ although expanded interaction also drew populations into new settlements by the first centuries CE,

35 Hall, Maritime Trade, 1985; Miriam T. Stark and Bong Sovath, "Recent Research on the Emergence of Early Historic States in Cambodia's Lower Mekong," Bulletin of the Indo-Pacific Prehistory Association 19 (2001): 92-94.

36 Ranjusri Ghosh, "Pundravardhana in the First Phase of Urbanization (4th Century B.C.-3rd Century A.D.) - A Study,” Proceedings of the Indian History Congress 57 (1996): 199-209; Sunil Gupta, "The Bay of Bengal Interaction Sphere (1000 BC-AD 500)," Bulletin of the Indo-Pacific Prehistory Association 25 (2005): 21-30; Himanshu Prabha Ray, "The Archaeology of Bengal: Trading Networks, Cultural Identities," Journal of the Social and Economic History of the Orient 49 (2006): 68-95.

37 Caitlin Evans, Nigel Chang, and Naho Shimizu, "Sites, Survey, and Ceramics: Settlement Patterns in the First to Ninth Centuries CE in the Upper Mun River Valley, Northeast Thailand," Journal of Southeast Asian Studies 47 (2016): 438-67; Heng, "Transition to the Pre-Angkorian Period"; Murphy and Stark, "Introduction," 335-336; Miriam T. Stark, "Early Mainland Southeast Asian Landscapes in the First Millennium AD," Annual Review of Anthropology 35 (2006): 407-32.

38 Aude Favereau and Bérénice Bellina, "Thai-Malay Peninsula and South China Sea Networks (500 BC-AD 200), Based on a Reappraisal of ‘Sa Huynh-Kalanay'-Related Ceramics,” Quaternary International 416 (2016): 219-27; Stark, "Early Mainland Southeast Asian Landscapes."

39 Carter, "Beads, Exchange Networks and Emerging Complexity," 751.

40 See Jan Wisseman Christie, "State Formation in Early Maritime Southeast Asia: A Consideration of the Theories and the Data," Bijdragen tot de Taal-, Land -en Volkenkunde 151 (1995): 235-88; Pierre-Yves Manguin, "The Archaeology of Early Maritime Polities of Southeast Asia," in Southeast Asia: From Prehistory to History, eds. Ian Glover and Peter Bellwood (New York: Routledge Curzon, 2004), 282-313.

41 Ambra Calo et al., "Sembiran and Pacung on the North Coast of Bali: A Strategic Crossroads for Early Trans-Asiatic Exchange,” Antiquity 89 (2015): 394. 
or the protohistoric period. ${ }^{42}$ South Asians practiced animist, Buddhist, and Brahmanic belief systems in both urban centers and their surrounding countrysides by the early centuries CE; ${ }^{43}$ South Asia's earliest Buddhist monasteries also appeared during this time. ${ }^{44}$

These protohistoric developments established the foundation upon which South and Southeast Asian subregions fluoresced in the mid-first millennium CE. Archaeologists and art historians have documented the materialization of both indigenous and South Asian ideologies and practices in places and goods from the "Gupta era" in Southeast Asia from the mid- to late third to the early seventh centuries CE. ${ }^{45}$ Peninsular South Asia, the Bay of Bengal, and much of mainland Southeast Asia underwent parallel cultural developments during this time. These included the ideological transmission of Indic ideologies and practices by lay people (particularly merchants and artisans) and elites, which are manifest in multireligious built landscapes. Jewelry, containers, and - somewhat later - stone and perhaps wooden statuary forged larger terrestrial and maritime cultural landscapes than ever before. ${ }^{46}$

A desire to participate in emerging economic and religious networks drew inland, agrarian populations to urban coastal settlements and emergent cities in alluvial floodplains. Their managerial elite embraced Brahmanic and Buddhist practices, which in turn required new physical trappings: writing on bamboo strips and sandstone stelae (not copper plates), institutionalized religion, ritual paraphernalia, and shrines and temples. These objects required caretakers: literati for the inscriptions; artisans for the amulets and ritual vessels; and geomancers,

42 Carter, "Beads, Exchange Networks and Emerging Complexity," 751; Miriam T. Stark, "Pre-Angkorian Settlement Trends in Cambodia's Mekong Delta and the Lower Mekong Archaeological Project," Bulletin of the Indo-Pacific Prehistory Association 26 (2006): 98-109. 43 See Jason D. Hawkes, "One Size Does Not Fit All: Landscapes of Religious Change in Vindhya Pradesh," South Asian Studies 30 (2014): 1-15; Ray, "The Archaeology of Bengal”; Julia Shaw, "Nāga Sculptures in Sanchi's Archaeological Landscape: Buddhism, Vaiṣnavism, and Local Agricultural Cults in Central India, First Century BCE to Fifth Century CE,” Artibus Asiae 64 (2004): 5-59.

44 Johannes Bronkhorst, Buddhism in the Shadow of Brahmanism (Leiden: Brill, 2011), 19.

45 See Alison Kyra Carter and Nam C. Kim, "Globalization at the Dawn of History: The Emergence of Global Cultures in the Mekong and Red River Deltas," in The Routledge Handbook of Archaeology and Globalization, ed. Tamar Hodos (London: Routledge Taylor \& Francis Group, 2017), 733-734 for a recent review.

46 Dalsheimer and Manguin, "Vișnu mitrés et réseaux marchands en Asie du Sud-Est"; Pierre-Yves Manguin, "City-States and City-State Cultures in Pre-15th-Century Southeast Asia," in A Comparative Study of Thirty City-State Cultures, ed. Mogens Herman Hansen (Copenhagen: Royal Danish Academy of Science and Letters, 2000), 409-16 and "The Archaeology of Early Maritime Polities of Southeast Asia.” 
architects, and ritual specialists for the shrines. With these new responsibilities came the emergence of a new elite that conveyed cultural and social order; writing and temple construction became vehicles of social power, ${ }^{47}$ and thirdcentury CE Chinese sources noted the books and archives of "Funan." "48 The next section tacks between current knowledge of the timing of changes in South Asian ritual, language, and networks in Gupta-period South Asia with respect to Southeast Asia.

\section{Material and Ideological Matters in South and Southeast Asia}

\subsection{South and Southeast Asia's Earliest Temples and Ritual Practice}

Historians can occasionally access the earliest vestiges of ancient religions through texts, but archaeologists generally record its later formalization through the study of sacred places, images, and ritual paraphernalia, like carved ring stones, terracotta images, and carnelian lions. ${ }^{49}$ Recent South Asian syntheses date the earliest durable structures in brick (shrines, caves, and rock shelters) associated with Buddhist and Brahmanic religions by the third and second centuries BCE. The early Mauryan construction date that Hawkes ${ }^{50}$ suggests for monastic buildings at the site of Deur Kothar (Madhya Pradesh) is significantly earlier than most other reports.

By this time, people built and patronized Buddhist monasteries and pilgrimage sites with stūpa complexes and Hindu apsidal shrines, often along trade routes, from the Western Ghats to the eastern coast of Peninsular India, including the Bay of Bengal region. ${ }^{51}$ Crossing cultural and political boundaries, these

47 See, e.g., Lavy, “As in Heaven, So on Earth.”

48 Paul Pelliot, “Le Fou-Nan,” Bulletin de l'École française d'Extrême-Orient, 3 (1903): 248-303, 254.

49 Lars Fogelin, An Archaeological History of Indian Buddhism (Oxford: Oxford University Press, 2015), 29; Upinder Singh, "Cults and Shrines in Early Historical Mathura (c. 200 BC-AD 200),” World Archaeology 36 (2004): 378-98.

50 Hawkes, “One Size Does Not Fit All,” 2.

51 E.g. Bronkhorst, Buddhism in the Shadow of Brahmanism, 19; Robin Coningham, "Monks, Caves and Kings: A Reassessment of the Nature of Early Buddhism in Sri Lanka," World Archaeology 27 (1995): 222-42; Fogelin, An Archaeological History of Indian Buddhism, 104-109; Neelis, Early Buddhist Transmission and Trade Networks, 207-208; Himanshu Prabha 
ideological systems circulated people and goods, forged communities through ritual practice, and merged religion and statecraft with both Sanskrit and Pali as liturgical languages by the mid-second century BCE. ${ }^{52}$

Asians on both sides of the Bay of Bengal adopted temple-based religion and its associated rituals, language, and political ideology by the fifth and sixth centuries CE. ${ }^{53}$ Reasons why priests moved their pūjā ritual practice from the domestic environment to public shrines and community temples have been discussed in depth elsewhere. ${ }^{54}$ At stake here is the process by which it took place, and why Southeast Asians embraced this shift relatively soon after it developed in South Asia in the fifth and sixth centuries CE. Southeast Asian archaeologists and art historians acknowledge both multiple aesthetic influences on Southeast Asia's earliest architecture and Buddhist and Brahmanic statuary; yet nearly all identify profoundly local stylistic traditions that distinguish the art from its South Asian counterparts. ${ }^{55}$

Ray, Monastery and Guild: Commerce under the Satavahanas (Delhi: Oxford University Press, 1986), "Early Maritime Contacts between South and Southeast Asia," and "The Archaeology of Bengal," 87; Julia Shaw, "Monasteries, Monasticism, and Patronage in Ancient India: Mawasa, a Recently Documented Hilltop Buddhist Complex in the Sanchi Area of Madhya Pradesh," South Asian Studies 27 (2011): 111-30 and "Archaeologies of Buddhist Propagation in Ancient India: 'Ritual' and 'Practical' Models of Religious Change,” World Archaeology 45 (2013): 93 et passim.

52 Bronkhorst, Buddhism in the Shadow of Brahmanism, 50; Ingo Strauch, "The Character Writing System Between Identity and Assimilation," in The Idea of Writing: Writing Across Borders, eds. Alex de Voogt and Joachim Friedrich Quack (Leiden: Brill, 2011), 149.

53 E.g., Robert L. Brown, "Importance of Gupta-Period Sculpture in Southeast Asian Art History," in Early Interactions between South and Southeast Asia: Reflections on Cross-Cultural Exchange, eds. Pierre-Yves Manguin, A. Mani, and Geoff Wade (Singapore: Institute for Southeast Asian Studies, 2011), 317-31; Michael de Havenon, "The Earliest Viṣnu Sculpture from Southeast Asia,” The Journal of the Walters Art Museum 64/65 (2006/2007): 81-98; Manguin, "The Transmission of Vaișnavism across the Bay of Bengal," 55. For the earliest suggestion, see Hermann Kulke, "Indian Colonies, Indianization or Cultural Convergence? Reflections on the Changing Image of India's Role in South-East Asia," in Onderzoek in Zuidoost-Azië: Agenda's voor de Jaren Negentig, ed. Henk S. Nordholt (Leiden: Rijksuniversiteit te Leiden, Vakgroep Talen en Culturen van Zuidoost-Azië en Oceanië, 1990), 8-32.

54 E.g., Willis, "The Formation of Temple Ritual in the Gupta Period."

55 Brown, "Importance of Gupta-Period Sculpture in Southeast Asian Art History"; Dalsheimer and Manguin, "Viṣnu mitrés et réseaux marchands en Asie du Sud-Est”; Heejung Kang, "The Spread of Sarnath-Style Buddha Images in Southeast Asia and Shandong, China, by the Sea Route," Kemanusiaan 20 (2013): 39-60; Paul A. Lavy, "Conch-on-Hip Images in Peninsular Thailand and Early Vaișnava Sculpture in Southeast Asia,” in Before Siam: Essays in Art and Archaeology, eds. Nicolas Revire and Stephen A. Murphy (Bangkok: River Books, 2014), 157-164; Janice Stargardt, "Death Rituals of the Late Iron Age and Early Buddhism in 
Southeast Asians erected their shrines and temples in communities where they had already lived for centuries: ${ }^{56}$ alluvial plains from the Irrawaddy and Chao Phraya rivers to the Mekong Delta. They filled these structures with Buddha statues and representations of deities, including Siva linga, Ganeśa, Sūrya, Brahmā, Mahișāsuramardinī, and Lakșmī. ${ }^{57}$ They so embraced literacy that third-century Chinese visitors described books and depots where Funan residents stored their archives. ${ }^{58}$ What remains for scholarly study are their intricately carved stone stelae, which favored vernacular languages by the seventh and eighth centuries. ${ }^{59}$ They also used Sanskrit and Khmer on their stelae, and archaic types of Brahmi and Pallava on gold plaques recovered from early brick foundations across southern Vietnam during the 1980s and 1990s, with the earliest examples from the Go Thap site.$^{60}$ Bronkhorst contends that within a few centuries a great majority of Brahmins in Southeast Asia were Southeast Asian, and some had studied in Indian ashrams. ${ }^{61}$

Central Burma and South-East India - Whose Norms, Whose Practices?" in Im Dickicht der Gebote; Studien zur Dialektik von Norm und Praxis in der Buddhsismusgeschichte Asiens, Historia Religionum 26, ed. Peter Schalk (Uppsala: Acta Universitatis Upsaliensis, 2005), 407-33.

56 E.g., Evans et al., "Sites, Survey, and Ceramics"; Heng, "Transition to the Pre-Angkorian Period"; Stephen A. Murphy, "The Case for Proto-Dvāravatī: A Review of the Art Historical and Archaeological Evidence," Journal of Southeast Asian Studies 47 (2016): 366-92; Stargardt, "From the Iron Age to Early Cities."For Gupta parallels, see Jason D. Hawkes and Riza Abbas, "Copperplates in Context: A Preliminary Investigation of the Study and Archaeological Settings of Land Grant Inscriptions," Pratnatattva 22 (2016): 51.

57 See Le Thi Lien, "Hindu Deities in Southern Vietnam: Images on Small Archaeological Artefacts," in Early Interactions between South and Southeast Asia: Reflections on CrossCultural Exchange, eds. Pierre-Yves Manguin, A. Mani, and Geoff Wade (Singapore: Institute for Southeast Asian Studies, 2011), 407-431; Stanley J. O’Connor, “Some Early Siva Linga in Nakorn Si Thammarat, Peninsular Thailand,” Journal of the Siam Society 71 (1983): 1-5.

58 Pelliot, "Le Fou-Nan," 254.

59 E.g., Michael Vickery, Society, Economics, and Politics in Pre-Angkor Cambodia: The 7th-8th Centuries (Tokyo: The Centre for East Asian Cultural Studies for Unesco, 1998).

60 Le Thi Lien, "Gold Plaques and Their Cultural Contexts in the Oc Eo Culture," Bulletin of the Indo-Pacific Prehistory Association 25 (2005): 145-54 and "Brahmi Inscriptions from Archaeological Sites in Southern Vietnam During the 1st Millennium CE," in Advancing Southeast Asian Archaeology 2013: Selected Papers from the First SEAMEO SPAFA International Conference on Southeast Asian Archaeology, Chonburi, Thailand 2013 (Bangkok: SEAMEO SPAFA Regional Centre for Archaeology and Fine Arts, 2015), 364-365.

61 Johannes Bronkhorst, "The Spread of Sanskrit in Southeast Asia," in Early Interactions between South and Southeast Asia: Reflections on Cross-Cultural Exchange, eds. Pierre-Yves Manguin, A. Mani, and Geoff Wade (Singapore: Institute for Southeast Asian Studies, 2011), 269. 


\subsection{The Adoption of Southeast Asian Writing Systems}

Southeast Asians' adoption of writing systems marks the start of the region's historical period. The earliest Sanskrit inscriptions have been recovered from eastern Borneo, western Java, and southern Vietnam, where scholars date the Vo Canh inscription to the third century CE on paleographical grounds. Writing on seals, intaglios, and rings from the Mekong Delta site of Oc Eo bears close resemblance to second- to fifth-century South Asian scripts. ${ }^{62}$ The first locallywritten inscription in Old Khmer, using a Brāhmī-derived script, was recovered from Angkor Borei and dates to $611 \mathrm{CE}^{63}$

Research across mainland Southeast Asia suggests variation in the timing and nature of Indic cultural transmission, particularly with regard to literacy. The Pyu may have been the earliest adopters, with third- and fourth-century Indic-derived writing on seals, reliquaries, and stone urns: Prakrit at Beikthano; Prakrit, Pali, and Pyu at Sri Ksetra. ${ }^{64}$ Sociopolitical transformations in the structure of leadership and urbanization accompanied such shifts. The factors that motivated Southeast Asians to embrace beliefs, practices, and religious specialists of Indic origin remains a matter of some debate. Oliver Wolters emphasized both popular devotionalism (and the introduction of modes of worship informed by bhakti theologies) and a view of religious specialists as carriers of efficacious ritual knowledge. ${ }^{65}$ Many elites welcomed Brahmanic ideas and perhaps even Brahmins themselves into their communities; such foreigners infused magical qualities into ritual knowledge and introduced Sanskrit language and epics (e.g., Mahābhārata, Rāmāyaṇa), showcased Brahmanic power, and conferred benefits on local rulers who allied with these newcomers. ${ }^{66}$

Scholars now agree that Early Southeast Asian Brahmanic and Buddhist practices and monumentality took localized forms reflecting, but not directly copying, traditions in neighboring South Asia. More germane to this chapter is the fact that institutionalized Indic traditions, and particularly religion and statecraft, did not materialize across much of Southeast Asia until the latter

62 De Casparis, "Palaeogeography as an Auxiliary Discipline," 381-382.

63 Georges Cœdès, "XXV. Deux inscriptions sanskrites du Fou-nan,” Bulletin de l'École française d'Extrême-Orient 31 (1931): 1-12.

64 Stargardt, "From the Iron Age to Early Cities," 342.

65 Oliver W. Wolters, History, Culture and Region in Southeast Asian Perspectives (Ithaca, NY: Southeast Asian Program, Cornell University, 1999), 107-125.

66 Johannes Bronkhorst, How the Brahmins Won: From Alexander to the Guptas, Handbook of Oriental Studies 30 (Leiden: Brill, 2016), 409-412; Wolters, History, Culture and Region in Southeast Asian Perspectives, 111. 
end of the Gupta period: nearly a millennium after the earliest evidence for contact. When it did, Southeast Asians created ritual-political landscapes, replete with shrines, temples, monastic establishments, ashrams, and pilgrimage centers that fundamentally restructured their political world. Archaeologists working in the Mekong Delta since World War II have studied this "Gupta-period” transition, which rippled across the Lower Mekong Basin within centuries to generate new cosmologies of power. The work of the Lower Mekong Archaeological Project in southern Cambodia since 1996 offers an archaeological case study of change and continuity.

\section{LOMAP Landscapes}

The Lower Mekong Basin was the crucible for developments leading to the ninthto fifteenth-century Angkorian state. Scholars now agree that communities across the basin were converging into complex polities during the early first millennium CE, but the earliest, best-documented case involves the "Kingdom of Funan."67 Third- and sixth-century Chinese visitors to this polity recorded its scale, organization, and political history for their rulers; emissarial missions between China and Funan involved the movement of goods, people, and ideas. ${ }^{68}$ A consensus now exists that one of Funan's most prominent capitals lay at the archaeological site of Angkor Borei, in southern Cambodia. The earliest dated Khmer inscription (611 CE) was found at this site. ${ }^{69}$ The small Phnom Da hills just south of Angkor Borei yielded the earliest dated eponymous Khmer art tradition, ${ }^{70}$ which epigrapher Georges Cœdès linked with Funan's last ruler, Rudravarman (ca. 514-539 CE). ${ }^{71}$

67 See Pelliot, "Le Fou-Nan.”

68 See reviews in Yoshiaki Ishizawa, "Chinese Chronicles of 1st-5th Century A.D. Funan, Southern Cambodia," in South East Asia \& China: Art, Interaction \& Commerce, eds. Rosemary Scott and John Guy, Colloquies on Art \& Archaeology in Asia 17 (London: University of London Percival David Foundation of Chinese Art, 1996), 11-31; Claude Jacques, "China and Ancient Khmer History," in South East Asia \& China, 32-40; Stark, "The Transition to History in the Mekong Delta."

69 Cœdès, "XXV. Deux inscriptions sanskrites du Fou-nan."

70 Pierre Dupont, "Les linteaux khmers du VII siecle," Artibus Asiae 15 (1952): 31-83 and La statuaire pre-angkorienne (Ascona, Switzerland: Artibus Asiae, 1955).

71 Georges Cœdès, Inscriptions du Cambodge, vol. 1 (Hanoi: L'École française d'ExtrêmeOrient, 1942), 155. 


\subsection{Material Remains}

Angkor Borei today remains a named location where more than 14,000 Cambodians live and farm (Figure 3). This 300-hectare walled and moated site contains deep subsurface deposits; more than fifteen moated mounds with collapsed brick architectural features and their associated ancient ponds are still visible within the settlement. ${ }^{72}$ Field investigations by the Lower Mekong Archaeological Project have demonstrated that the site was first occupied in the fifth and fourth centuries $\mathrm{BCE},{ }^{73}$ construction of its encircling brick wall began as early as the first century $\mathrm{CE},{ }^{74}$ and its water sources are much older; ${ }^{75}$ its human burial population was relatively healthy, compared with populations further north, and bore little sign of interpersonal violence. ${ }^{76}$ The city had intimate links through artificial channels to a range of satellite communities to its west and south. ${ }^{77}$ Site excavations produced findings that parallel Louis Malleret's earlier work done in Vietnam's Mekong Delta, ${ }^{78}$ and more recent work since the 1970 s. $^{79}$

72 See Miriam T. Stark, “Angkor Borei and the Archaeology of Cambodia's Mekong Delta," in Art \& Archaeology of Fu Nan: Pre-Khmer Kingdom of the Lower Mekong Valley, ed. J. Khoo (Bangkok: Orchid Books, 2003), 87-106; Stark et al., "Results of the 1995-1996 Archaeological Field Investigations at Angkor Borei, Cambodia," Asian Perspectives 38 (1999): 7-36.

73 Stark and Bong, "Recent Research on the Emergence of Early Historic States."

74 Stark, Sanderson, and Bingham, "Monumentality in the Mekong Delta: Luminescence Dating and Implications."

75 Paul Bishop et al, "A 3.5ka Record of Paleoenvironments and Human Occupation at Angkor Borei, Mekong Delta, Southern Cambodia,” Geoarchaeology 18 (2003): 1-35.

76 Ikehara-Quebral et al., "Biocultural Practices During the Transition to History"; Michael Pietrusewsky and Rona M. Ikehara-Quebral, "The Bioarchaeology of the Vat Komnou Cemetery, Angkor Borei, Cambodia,” Bulletin of the Indo-Pacific Prehistory Association 26 (2006): 86-97.

77 Paul Bishop, David C. W. Sanderson, and Miriam T. Stark, "OSL and Radiocarbon Dating of a Pre-Angkorian Canal in the Mekong Delta, Southern Cambodia," Journal of Archaeological Science 31 (2003): 319-36; David C. W. Sanderson et al., "Luminescence Dating of Anthropogenically Reset Canal Sediments from Angkor Borei, Mekong Delta, Cambodia," Quaternary Science Reviews 22 (2003): 1111-1121; Stark, Sanderson, and Bingham, "Monumentality in the Mekong Delta: Luminescence Dating and Implications."

78 L. Malleret, L'Archéologie du Delta du Mekong (Paris: Publication de I’École française d'Extrême-Orient, 1959-1963).

79 E.g., Linh Côn Dao, "The Oc Eo Burial Group Recently Excavated at Go Thap (Dong Thap Province, Viêt Nam)," in Southeast Asian Archaeology 1994: Proceedings of the 5th International Conference of the European Association of Southeast Asian Archaeologists, vol. 1, ed. Pierre-Yves Manguin (Hull: Centre for Southeast Asian Studies, University of Hull, 1998), 111-17; Van Tan Ha, “Oc Eo: Endogenous and Exogenous Elements,” Vietnam Social Sciences 1-2 (1986): 91-101; Pierre-Yves Manguin and Vo Si Khai, "Excavations at the Ba The/Oc Eo Complex (Viet Nam): A Preliminary Report on the 1998 Campaign," in Southeast Asian Archaeology 1998: Proceedings of 


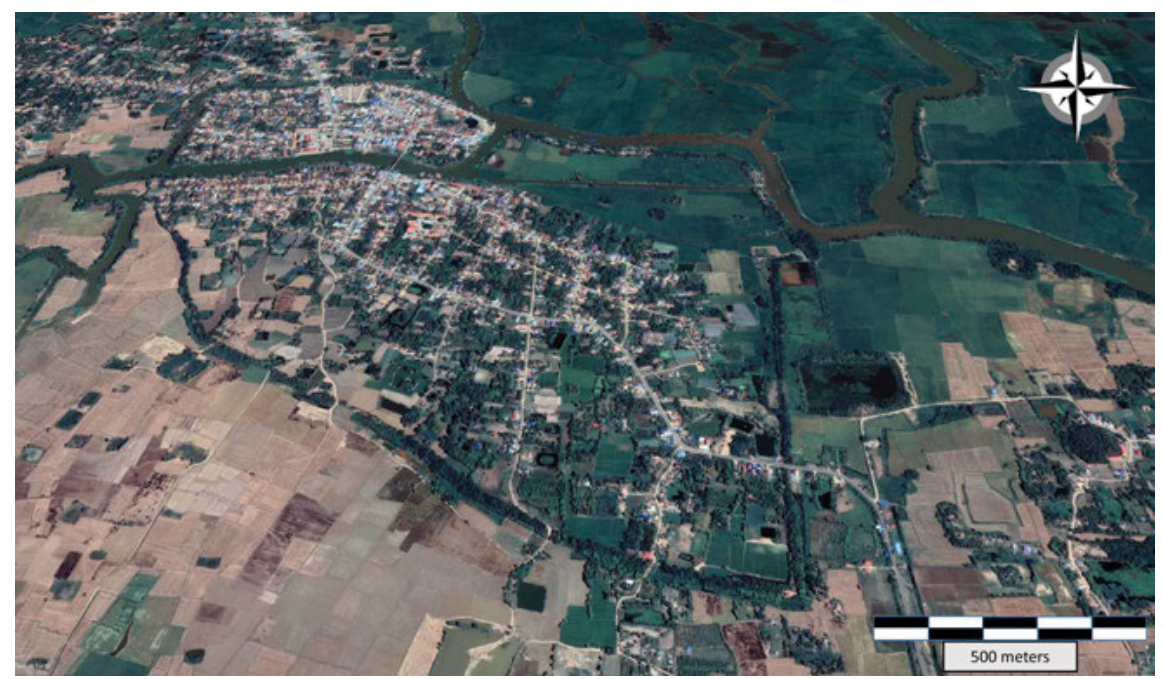

Figure 3: Angkor Borei archaeological site (Takeo Province, Cambodia) using Google map as a base map.

Four seasons of systematic archaeological field survey produced a robust settlement history for the Takeo River catchment in which Angkor Borei is located. ${ }^{80}$ LOMAP findings from Angkor Borei and from the 2003 to 2009 field survey, coupled with Vietnamese field investigations of "Oc Eo Culture" sites, offer patterns for comparison against "Gupta South Asia" in three domains. Most documented first-millennium CE sites were small mounds containing vestiges of collapsed brick features (Figure 4), most of which had been scavenged; only two tall (i.e., $>10$ meters in height) mounds were recorded that contained ostensibly intact brick temples. Figure 5 illustrates the fragmentary nature of brick architecture in most mapped mounds. Mounds that were mapped in rural areas associated with neighboring settlements appeared either as isolates or in small dispersed groups; most were moated, and pond depressions were still visible in locations where farmers had not infilled the areas for farming. Moated and non-moated mounds also appeared in villages atop archaeological sites, but Angkor Borei was the

the 7th International Conference of the European Association of Southeast Asian Archaeologists, eds. Wibke Lobo and Stefanie Reimann (Hull: Centre for South-East Asian Studies, University of Hull, 2000), 107-21; Trinh Thi Hòa, "Réflexions sur les vestiges de la culture d'Óc Eo,” Etudes Vietnamiennes, n. s., 50 (1996): 111-23.

80 Stark, "Pre-Angkorian Settlement Trends in Cambodia's Mekong Delta"; Stark, Sanderson, and Bingham, "Monumentality in the Mekong Delta: Luminescence Dating and Implications." 

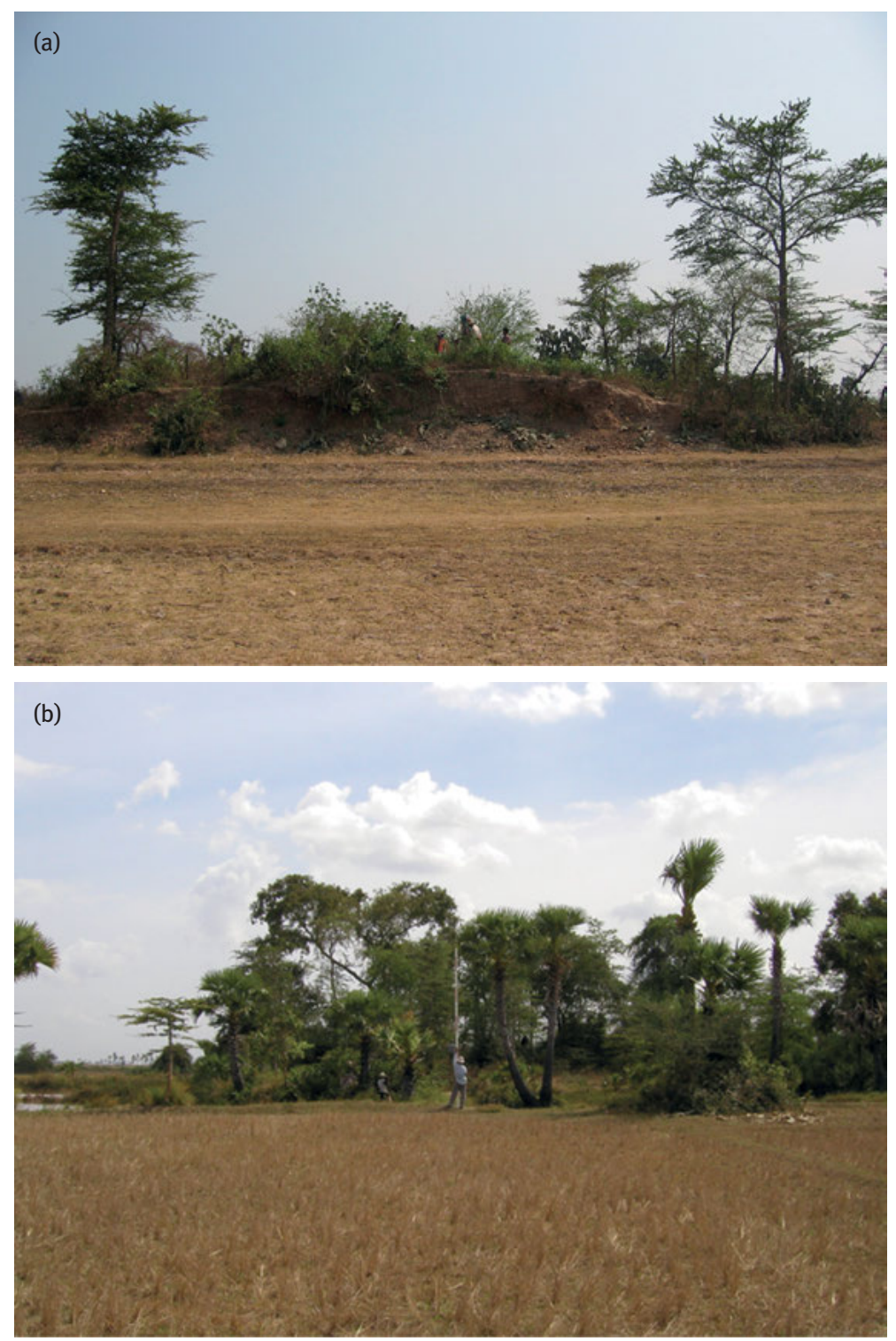

Figure 4: Mapping Pre-Angkorian archaeological sites from LOMAP 2004 Survey. 4a (top): Ang Neakta Chhvia; 4b (bottom): Tuol Kpuos. 

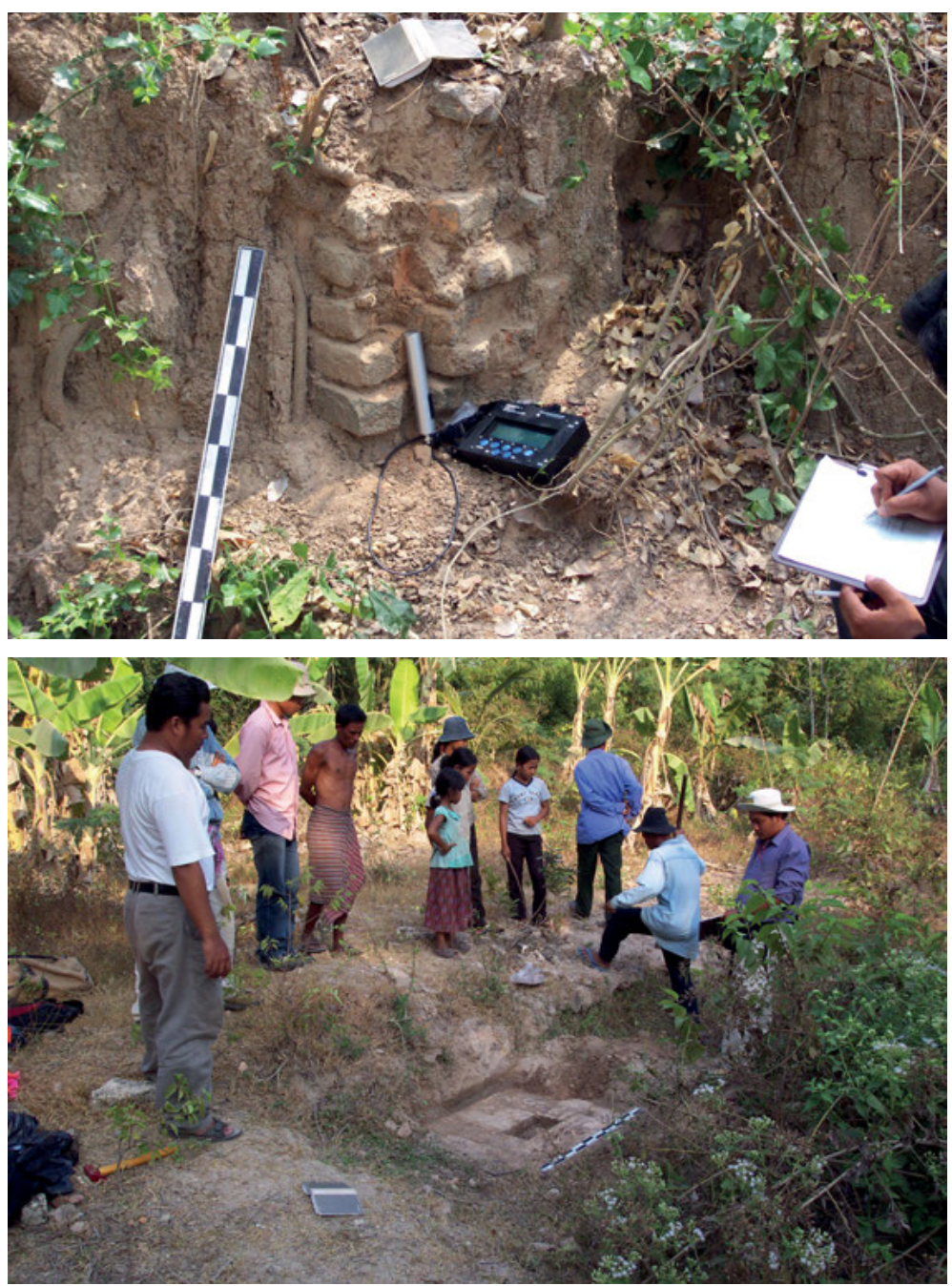

Figure 5: Examples of dated fragmentary brick structures in LOMAP region: (upper) Ang Yay Nuon. OSL date: $650 \pm 50$ CE. (lower) Ta Tos (Angkor Borei site). OSL dates: $320 \pm 30$ CE (SUTL 1565), 95 \pm 30 CE (SUTL 1566), $570 \pm 30$ CE (SUTL 1567). In Stark et al. (2006:115, Table 2). 
only nucleated settlement with more than ten mapped small mounds and at least two large temples. ${ }^{81}$

Smaller brick structures that have been documented in both southern Vietnam and southern Cambodia were likely Hindu and Buddhist shrines, ${ }^{82}$ based both on their dimensions and original contents. Most mounds that our 2003 to 2009 LOMAP survey (Takeo Province, Cambodia) mapped had been excavated previously by villagers in search of gold; they consistently reported, with great disappointment, that soundings in the mounds' centers produced objects associated with ritual deposits (e.g., inscribed and/or decorated gold leaves; four bricks placed in a square that Ślączka links to the Prathameștakanyāsa consecration ritual; ${ }^{83}$ and white sand), rather than abundant gold caches. Larger mapped structures, some ranging up to 70 meters in length, are presumed to have served as temples. Most have been partly or completely destroyed; one from Angkor Borei yielded at least three Brahmanic images in the late 1990s during its dismantlement. Rural hamlets had shrines; nucleated villages had shrines and, later in the sequence, large brick temples. Physical manifestations of institutionalized Brahmanism and Buddhism (temples, shrines, statuary, and inscribed stelae) were transformative objects in the past. Collectively, such features produced ritual landscapes, ${ }^{84}$ in which some settlements like Angkor Borei were sufficiently nucleated to be considered urban. That such ritual structures were established in locations of traditional indigenous neak ta ancestral spirits ${ }^{85}$ suggests both a merging of religious and political, and the kind of ideological multivocality that also characterized fifth- and sixth-century Gupta India from its core region to Tamil Nadu and the Bay of Bengal. ${ }^{86}$ In both South and Southeast Asia, populations tolerated Buddhism and established monastic centers under rulers who patronized Brahmanism. Epigraphic and art-historical evidence from the Mekong Delta suggests both Vaiṣnava and Saiva practice during the first millennium

81 Stark et al., "Results of the 1995-1996 Archaeological Field Investigations," 20-22; Stark, "Pre-Angkorian Settlement Trends in Cambodia's Mekong Delta."

82 Ślączka, Anna Aleksandra, "The Depositing of the Embryo: Temple Consecration Rituals in the Hindu Tradition of South and Southeast Asia: A Study of the Textual and Archaeological Evidence," in Early Interactions between South and Southeast Asia: Reflections on CrossCultural Exchange, eds. Pierre-Yves Manguin, A. Mani, and Geoff Wade (Singapore: Institute for Southeast Asian Studies, 2011), 433-42 and "The Brick Structures of Go Thap: Tombs or Temples?” Bulletin of the Indo-Pacific Prehistory Association 31 (2011): 109-117.

83 Ślączka, "The Depositing of the Embryo," 437.

84 See Stark, "Inscribing Legitimacy and Building Power in the Mekong Delta," 75-105.

85 Vickery, Society, Economics, and Politics in Pre-Angkor Cambodia, 309.

86 Ray, Archaeology and Buddhism in South Asia, 71, 115. 
CE. ${ }^{87}$ Figure 6 illustrates a pre-Angkorian Siva linga in situ at the Kampong Youl community in 1997 before its removal to the Angkor Borei Museum; the subsequent LOMAP survey mapped both first-millennium CE mounds and residential areas at this location.

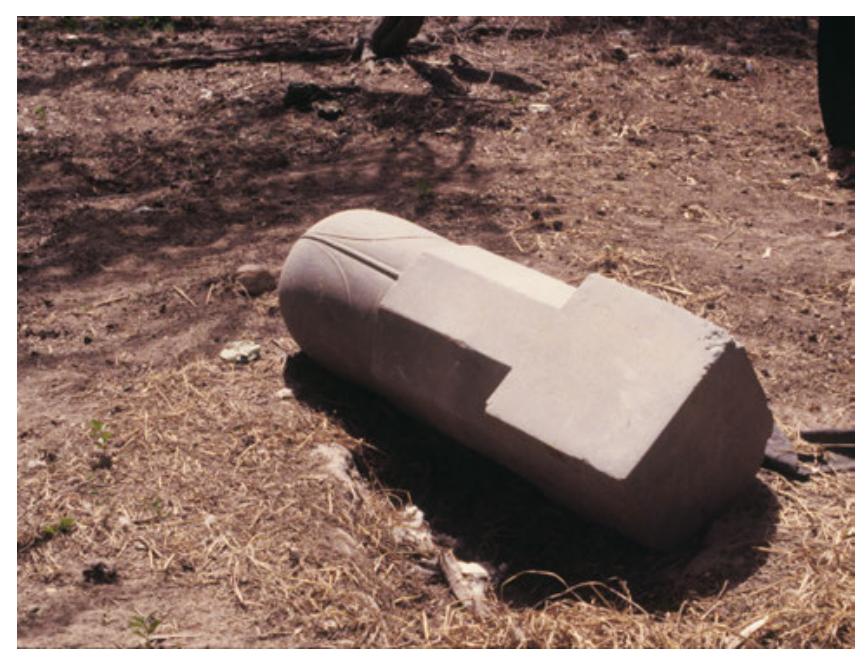

Figure 6: Pre-Angkorian linga in situ at Kampong Youl village, Takeo Province, Cambodia (July 1997).

\subsection{Materializing Political Organization}

Who were these rulers, and what was the sociopolitical framework in which they rose to power? Pre-Angkorian elite donors with hereditary poñ titles sponsored sixth- and seventh-century CE inscriptions across the Lower Mekong Basin and lived within broader communities guided by headmen and perhaps even councils of elders - not unlike the fifth- and sixth-century adhikarana or councils that administered Puṇ̂ravardhana in north Bengal, based on copperplate land grants, ${ }^{88}$ although such administration became more centralized

87 E.g., Cœedès, "XXV. Deux inscriptions sanskrites du Fou-nan"; Lavy, "As in Heaven, So on Earth"; Le Thi Lien, "Gold Plaques and Their Cultural Contexts," "Hindu Deities in Southern Vietnam," and "Brahmi Inscriptions from Archaeological Sites”; Malleret, L'Archéologie du Delta du Mekong; Manguin and Vo Si Khai, "Excavations at the Ba The/Oc Eo Complex."

88 R. Furui, "Variegated Adaptations: State Formation in Bengal from the Fifth to Seventh Century," in Interrogating Political Systems: Integrative Processes and States in Pre-Modern India, eds. Bhairavi Prasad Sahu and Hermann Kulke (New Delhi: Manohar, 2015), 259-264. 
through this period. ${ }^{89}$ Perhaps matrilineal in organization, local lineages may have controlled land collectively. ${ }^{90}$ We cannot identify specific landholding estates or monastic centers on the contemporary landscape, but epigraphic sources suggest the replacement of hereditary pon titles in the eighth century with the new mratān title. Historians equate this change in title with the gradual assumption of power by non-poñ rulers, ${ }^{91}$ a change that coincided with the emergence of multiple polities across the Lower Mekong Basin. ${ }^{92}$

Consolidating power in ancient Cambodia depended on building and maintaining linkages with elites elsewhere in the region, and archaeologists can explore the time depth and directionality of some of these networks by studying language, objects, and architecture. Technological studies of stone and glass materials (frequently but not always beads) recovered from Iron Age and protohistoric burials across the Lower Mekong and into Peninsular Thailand suggests multiple sequential phases of South/Southeast Asia interaction that began in the mid-first millennium BCE and intensified through time. Glass and stone beads, carnelian lion pendants and high-tin knobbed bronze bowls from South Asia have been recovered from second- and first-century BCE sites from Vietnam to Myanmar, ${ }^{93}$ suggesting movement between regions and likely using the Bay of Bengal. ${ }^{94}$ Linguistic and maritime studies indicate that Southeast Asian seafarers likely dominated the interchange. ${ }^{95}$ South Asians sought Southeast Asian goods:

89 Arlo Griffiths, "New Documents for the Early History of Pundravardhana: Copperplate Inscriptions from the Late Gupta and Early Post-Gupta Periods," Pratna Samiksha: A Journal of Archaeology, n. s., 6 (2015): 25-26.

90 Vickery, Society, Economics, and Politics in Pre-Angkor Cambodia, 299, 324.

91 Vickery, Society, Economics, and Politics in Pre-Angkor Cambodia, 372-379.

92 See Heng, "Transition to the Pre-Angkorian Period”; Claude Jacques, “'Funan', 'Zhenla': The Reality Concealed by These Chinese views of Indochina," in Early South East Asia: Essays in Archaeology, History and Historical Geography, eds. R. B. Smith and W. Watson (Oxford: Oxford University Press), 371-379.

93 Ian C. Glover and Bérénice Bellina, "Ban Don Ta Phet and Khao Sam Kaeo: The Earliest Indian Contacts Re-Assessed," in Early Interactions between South and Southeast Asia: Reflections on Cross-Cultural Exchange, eds. Pierre-Yves Manguin, A. Mani, and Geoff Wade (Singapore: Institute of Southeast Asian Studies, 2011), 17-45.

94 See Ray, Winds of Change, 1994.

95 Hoogervorst, "Tracing Maritime Connections,” 2017; Pierre-Yves Manguin, “Trading Ships of the South China Sea. Shipbuilding Techniques and Their Role in the History of the Development of Asian Trade Networks," Journal of the Economic and Social History of the Orient 36 (1993): 255-264 and "Ships and Shipping in Southeast Asia," Oxford Research Encyclopedia of Asian History, ed. David Ludden (Oxford: Oxford University Press, 2017). 
tin, copper, tortoiseshell, aromatic tree products, and food crops were all transported westward. ${ }^{96}$

By the fourth century CE, earthenware ceremonial objects like spouted ewers (kendi) appear in Thailand, ${ }^{97}$ southern Cambodia, ${ }^{98}$ and southern Vietnam. ${ }^{99}$ Figure 7 illustrates three nearly complete but unprovenanced kendi vessels from the Angkor Borei Museum that villagers recovered. LOMAP excavations recovered kendi sherds (primarily spouts) that date to the third to sixth centuries CE. ${ }^{100}$ This vessel form appears in coastal and inland sites whose inhabitants participated in a pan-South China Sea network whose origins may lie nearly a millennium earlier in time. ${ }^{101}$ Made from fine alluvial clays, this painted or plain fine-paste vessel form exhibits little variation in form irrespective of provenance and suggests a shared ceramic technological tradition whose horizon encompassed the entire region in which Southeast and South Asians interacted in the early to mid-first millennium CE.

The South Asian provenance of some objects, and a larger number of objects reflecting South Asian technological traditions, ${ }^{102}$ supports historians' contention that people and ideas moved freely between South and Southeast Asia. So does the appearance of mid-fifth-century Sanskrit inscriptions, some of which are in Tamil Grantha script, and mitered Viṣnus along the coasts of Java, Borneo, and Sumatra. ${ }^{103}$ In nearly every instance, Southeast Asians added their distinct signature to ideas and objects that originated in South Asia, and developed these South Asian-infused objects at different points in the sequence.

96 Tom Hoogervorst, "If Only Plants Could Talk . . . Reconstructing Pre-Modern Biological Translocations in the Indian Ocean," in The Sea, Identity and History: From the Bay of Bengal to the South China Sea, eds. Satish Chandra and Himanshu Prabha Ray (New Delhi: Manohar Press, 2013), 67-92; Hoogervorst, “Tracing Maritime Connections,” 2017: 760-761.

97 A. Barram and Ian C. Glover, "Rethinking Dvaravati," in Archaeology in Southeast Asia from Homo erectus to the Living Traditions, ed. J.- P. S. Méry, V. Zeitoun and E. Rambault (Chiang Mai: European Association of Southeast Asian Archaeologists, 2008) 175-182; 180, Table 1.

98 Miriam Stark, "Pre-Angkor Earthenware: Ceramics from Cambodia’s Mekong Delta," Udaya: Journal of Khmer Studies 1 (2000): 69-89.

99 Masanari Nishimura, Nguyễn Duy Tỷ, and Huỳnh Đình Chung, "Excavation of Nhơn Thành at the Hậu Giang River Reach, Southern Vietnam,” Taida Journal of Art History 25 (2009): 1-68.

100 Miriam T. Stark and Shawn Fehrenbach, "Earthenware Ceramic Technologies of Angkor Borei, Cambodia," Udaya, Journal of Khmer Studies 14 (2019): 116.

101 E.g., Favereau and Bellina, "Thai-Malay Peninsula and South China Sea Networks."

102 E.g., Carter, "Garnet Beads in Southeast Asia."

103 Dalsheimer and Manguin, "Viṣnu mitrés et réseaux marchands en Asie du Sud-Est"; Guy, "Tamil Merchants and the Hindu-Buddhist Diaspora," 244-248. 

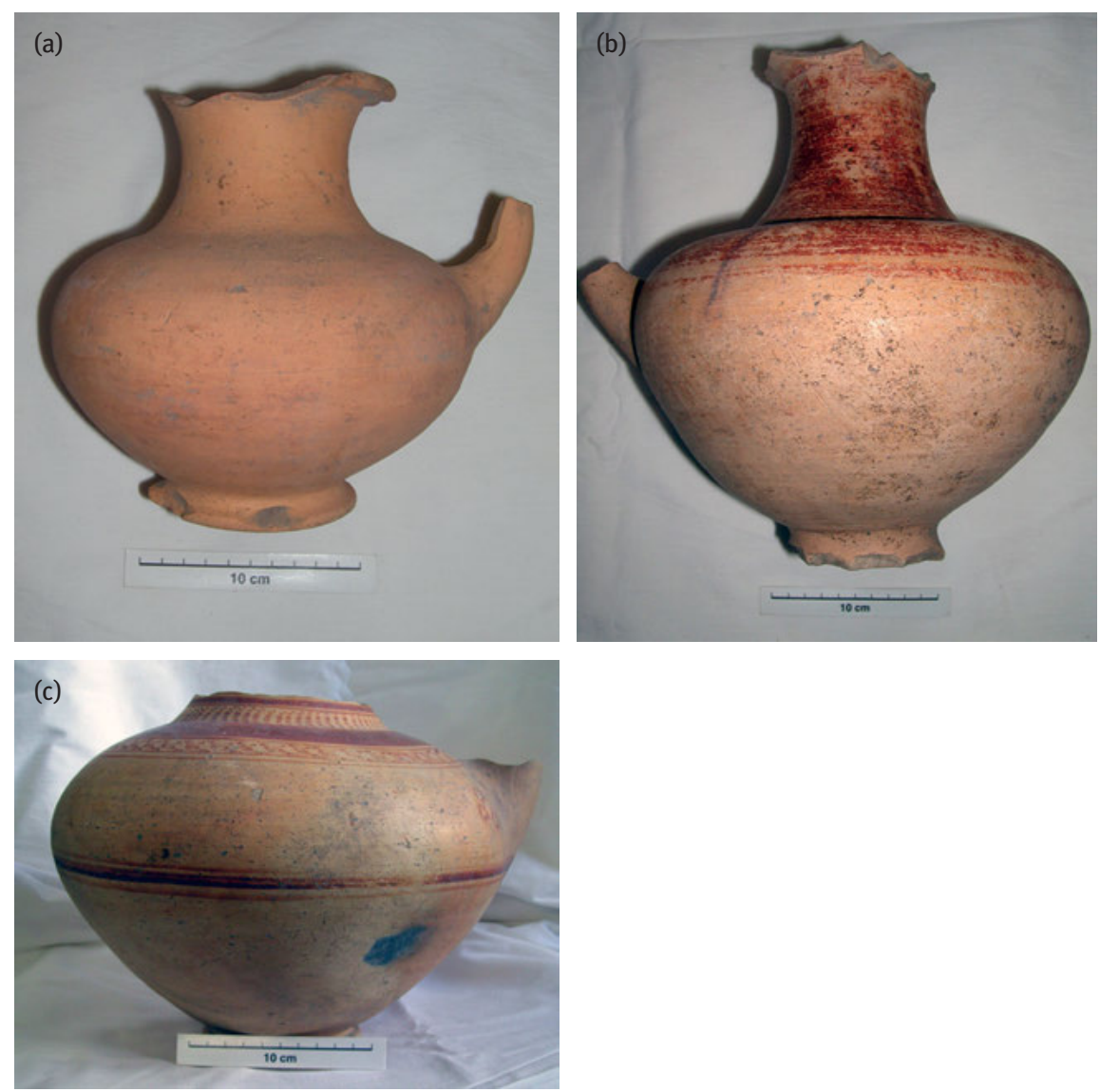

Figure 7: Examples of kendi vessel forms housed at the Angkor Borei Museum (Takeo Province, Cambodia).

\section{Luminescence, Tempo, and Change}

This chapter has summarized recent research in the Lower Mekong Basin to understand the dynamic modes of cultural production in the first millennium CE that ultimately transformed the region into urbanized state-level societies. The wealth of "Indic" evidence that appeared shortly after the mid-first millennium suggests that the area's populations joined the pre-existing South China Sea network during the early centuries CE. ${ }^{104}$ What happened in the Mekong Delta

104 See Carter, "Beads, Exchange Networks and Emerging Complexity.” 
during the "Gupta era" was thus something new, demographically as well as organizationally. A growing body of archaeological, art-historical, and epigraphic research suggests a mid-sixth-century CE date for organizational transformations across the Lower Mekong and Chao Phraya basins, ${ }^{105}$ and contemporary inscribed Pyu stone burial urns bearing royal names that reflect Sanskrit origins ${ }^{106}$ suggests that Gupta India resonated with a broad audience to its east. Refining the timing of South Asian and Southeast Asian developments is challenging on many counts: both regions housed discrete, if interacting, polities during the mid-first millennium CE; art historians hold differing views regarding the timing of some of Southeast Asia's earliest Brahmanic art; ${ }^{107}$ and few radiometric dates exist for monuments that would have been the centers of communal ritual practice. We know, however, that Buddhism and its practitioners reached southern India and the Bay of Bengal by the late centuries BCE. ${ }^{108}$ Southeast Asia's westernmost Pyu embraced monastic centers by the early centuries CE. ${ }^{109}$

Archaeologists have now documented protohistoric settlement in most Southeast Asian places where these fifth- and sixth-century temple communities developed. The timing of this emergence varied across the region, but arthistorical and archaeological evidence suggests that most polities were in conversation with institutionalized ideologies through the movement of people and goods. So did hearing the Sanskrit epics that these Brahmins carried, which illustrated Brahmanic power and mapped neatly onto traditional Southeast Asian tutelary spirits. We lack clear evidence that evangelizing Buddhist monks on the move after the fifth-century collapse of Gandharan patronage ${ }^{110}$ reached Southeast Asian

105 Brown, "Importance of Gupta-Period Sculpture in Southeast Asian Art History”; Murphy, "The Case for Proto-Dvāravatī”; Stark, "Early Mainland Southeast Asian Landscapes."

106 Stargardt, "From the Iron Age to Early Cities," 358-359.

107 E.g., de Havenon, "The Earliest Vișṇu Sculpture from Southeast Asia”; Lavy, "Conch-onHip Images in Peninsular Thailand”; Stanley J. O’Connor, Hindu Gods of Peninsular Siam, Supplementum 28 (Ascona, Switzerland: Artibus Asiae, 1972).

108 See Neelis, Early Buddhist Transmission and Trade Networks, 319; Himanshu Prabha Ray, "Multi-Religious Maritime Linkages Across the Bay of Bengal During the First Millennium CE," in Before Siam: Essays in Art and Archaeology, eds. Nicolas Revire and Stephen A. Murphy (Bangkok: River Books, 2014), 135-51.

109 Stargardt, "From the Iron Age to Early Cities," 353.

110 Kurt Behrendt, "Evidence for the Diffusion of Gandhara Forms after the Late 5th Century," in South Asian Religions and Visual Forms in their Archaeological Context, South Asian Archaeology and Art 2012, vol. 2, eds. Vincent Lefèvre, Aurore Didier, and Benjamin Mutin (Turnhout, Belgium: Brepols Publishers), 407-408; for Chinese parallel, see Neelis, Early Buddhist Transmission and Trade Network, 306. 
shores; better evidence exists for entrepreneurial Brahmins and artisans who traveled to Southeast Asian shores in search of better lifeways. ${ }^{111}$ Skilling's work shows how the dynamics of relic and image worship facilitated the eastward spread of Buddhism, ${ }^{112}$ with a particular focus on Avalokiteśvara and post-sixth-century ritual Buddhist images (e.g. clay seals, plaques, tablets, stūpa images) across much of Thailand and Cambodia.

Rules changed as ideas moved eastward: statuary took new forms that acknowledged South Asian origins but adapted to local traditions. ${ }^{113}$ Within generations, mainland Southeast Asians embraced the ideo-technological package of image-focused and temple-based Indic ideological systems. ${ }^{114}$ Why did Southeast Asians wait until the mid-first millennium CE to adopt these practices, rather than doing so centuries earlier? Perhaps it was the shift to temple-based ritual, occurring in Gupta-period South Asia, that persuaded them? Indic iconography and statuary had broad appeal in mainland and island Southeast Asia: fifth- to seventhcentury mitered Viṣnus and Bhadrasāna Buddhas with the vitarkamudrā have been recovered from sites across the mainland's river valleys and in settlements flanking the coasts of the South China Sea. ${ }^{115}$ Understanding the tempo and scale of artistic dialogue, cultural transmission, or missionary zeal behind these social transformations that swept Monsoon Asia during the mid-first millennium CE requires transdisciplinary and transnational approaches. We cannot explain why Mekong Delta populations embraced Indic iconography and practices when they did, but scholars working in both South and Southeast Asia have much to contribute to the quest to situate Gupta Age developments within the broader premodern world in which they took place.

111 Skilling, "Buddhism and the Circulation of Ritual," 373.

112 Skilling, "Buddhism and the Circulation of Ritual," 374.

113 See Robert L. Brown, “Rules' for Change in the Transfer of Indian Art to Southeast Asia," in Ancient Indonesian Sculpture, eds. Marijke J. Klokke and Pauline Lunsingh Sheurleer (Leiden: KITLV Press, 1994), 10-22.

114 Gregory Schopen, “On Monks, Nuns, and 'Vulgar Practices': The Introduction of the Image Cult into Indian Buddhism,” Artibus Asiae 49 (1988-1989): 153-168, 155; Willis, "The Formation of Temple Ritual in the Gupta Period."

115 Dalsheimer and Manguin, "Viṣnu mitrés et réseaux marchands en Asie du Sud-Est"; Nicolas Revire, "New Perspectives on the Origin and Spread of Bhadrasāna Buddhas throughout Southeast Asia (7th-8th centuries CE)," in Connecting Empires and States: Selected Papers from the 13th International Conference of the European Association of Southeast Asian Archaeologists, eds. Mai Lin Tjoa-Bonatz, Andreas Reinecke, and Dominik Bonatz (Singapore: NUS Press Pte Ltd, 2012), 131; Nicholas Revire, "From Gandhara to Java: A Comparative Study of Bhadrasana Buddhas and their related Bodhisattva Attendants in South and Southeast Asia,” in India and Southeast Asia: Cultural Discourses, ed. Anna L. Dallapiccola (Mumbai: K.R. Cama Cultural Institute, 2017) 280-304. 
Acknowledgments: Field research summarized in this paper was supported by the National Science Foundation (NSF \#0242327), the NASA Space Archaeology Program (Grant NNX08A26G), and a Center for Khmer Studies grant from the Rockefeller Foundation. I am grateful to Cambodia's Ministry of Culture and Fine Arts for permission to do research in Takeo Province, and to provincial, district, and local authorities for facilitating the field research. Thanks also go to the Archaeology Faculty at the Royal University of Fine Arts, whose staff and students were LOMAP crew members. I am also immensely grateful to Paul Lavy, Janice Stargardt, Elizabeth Cecil, and Peter Bisschop for comments and suggestions, and to David Sanderson for sharing field photographs as illustrations. Presentations at the 2018 Asia Beyond Boundaries conference (Leiden) were helpful in contextualizing my work. All responsibilities rest with the author.

\section{Bibliography}

Barram, A. and Ian C. Glover. "Rethinking Dvaravati." In Archaeology in Southeast Asia - from Homo erectus to the Living Traditions, edited by J.- P. S. Méry, V. Zeitoun and E. Rambault, 175-182. Chiang Mai: European Association of Southeast Asian Archaeologists, 2008.

Behrendt, Kurt. Evidence for the Diffusion of Gandhara Forms after the Late 5th Century. In South Asian Religions and Visual Forms in their Archaeological Context, edited by Vincent Lefèvre, Aurore Didier, and Benjamin Mutin, 407-16. South Asian Archaeology and Art 2012, vol. 2. Turnhout, Belgium: Brepols Publishers, 2016.

Bellina, Bérénice. "Maritime Silk Roads' Ornament Industries: Socio-Political Practices and Cultural Transfer in the South China Sea." Cambridge Archaeological Journal 24 (2014): 345-77.

Bellina, Bérénice, and lan Glover. "The Archaeology of Early Contact with India and the Mediterranean World, from the Fourth Century BC to the Fourth Century AD." In Southeast Asia: From Prehistory to History, edited by lan Glover and Peter Bellwood, 68-88. New York: Routledge Curzon, 2004.

Bellina-Pryce, Bérénice, and Praon Silapanth. "Khao Sam Kaeo and the Upper Thai Peninsula: Understanding the Mechanisms of Early Trans-Asiatic Trade and Cultural Exchange." In Uncovering Southeast Asia's Past: Selected Papers from the 10th International Conference of the European Association of Southeast Asian Archaeologists, edited by Elisabeth A. Bacus, Ian C. Glover, and Vincent C. Pigott, 379-392. Singapore: NUS Press, 2006.

Bishop, Paul D., Dan Penny, Miriam T. Stark, and Marian Scott. “A 3.5ka Record of Paleoenvironments and Human Occupation at Angkor Borei, Mekong Delta, Southern Cambodia." Geoarchaeology 18 (2003): 1-35.

Bishop, Paul M., David C. W. Sanderson, and Miriam T. Stark. "OSL and Radiocarbon Dating of a Pre-Angkorian Canal in the Mekong Delta, Southern Cambodia." Journal of Archaeological Science 31 (2003): 319-36.

Bronkhorst, Johannes. Buddhism in the Shadow of Brahmanism. Leiden: Brill, 2011. 
Bronkhorst, Johannes. "The Spread of Sanskrit in Southeast Asia." In Early Interactions between South and Southeast Asia; Reflections on Cross-Cultural Exchange, edited by Pierre-Yves Manguin, A. Mani, and Geoff Wade, 263-76. Singapore: Institute for Southeast Asian Studies, 2011.

Bronkhorst, Johannes. How the Brahmins Won: From Alexander to the Guptas. Handbook of Oriental Studies, Section Two: South Asia, vol. 30. Leiden: Brill, 2016.

Brown, Robert L. "Indian Art Transformed: The Earliest Sculptural Styles of Southeast Asia." In Indian Art and Archaeology, edited by Ellen M. Raven and Karel R. Van Kooij, 40-53. Leiden: Brill, 1992.

Brown, Robert L. “'Rules' for Change in the Transfer of Indian Art to Southeast Asia.” In Ancient Indonesian Sculpture, edited by Marijke J. Klokke and Pauline Lunsingh Sheurleer, 10-22. Leiden: KITLV Press, 1994.

Brown, Robert L. "Importance of Gupta-Period Sculpture in Southeast Asian Art History." In Early Interactions between South and Southeast Asia: Reflections on Cross-Cultural Exchange, edited by Pierre-Yves Manguin, A. Mani, and Geoff Wade, 317-31. Singapore: Institute for Southeast Asian Studies, 2011.

Calo, Ambra, Bagyo Prasetyo, Peter Bellwood, James W. Lankton, Bernard Gratuze, Thomas Oliver Pryce, Andreas Reinecke, Verena Leusch, Heidrun Schenk, Rachel Wood, Rochtri A. Bawono, I Dewa Kompiang Gede, Ni L.K. Citha Yuliati, Jack Fenner, Christian Reepmeyer, Cristina Castillo, and Alison Kyra Carter. "Sembiran and Pacung on the North Coast of Bali: A Strategic Crossroads for Early Trans-Asiatic Exchange.” Antiquity 89 (2015): 378-96.

Cameron, Judith. "Iron and Cloth Across the Bay of Bengal: New Data from Tha Kae, Central Thailand." Antiquity 85 (2011): 559-57.

Carter, Alison Kyra. "Garnet Beads in Southeast Asia: Evidence for Local Production?" In Crossing Borders in Southeast Asian Archaeology. Selected Papers from the 13th International Conference of the European Association of Southeast Asian Archaeologists, vol. 1, edited by Dominik Bonatz, Andreas Reinecke, and Mai Lin TjoaBonatz, 296-306. Singapore: NUS, 2012.

Carter, Alison Kyra. "Beads, Exchange Networks and Emerging Complexity: A Case Study from Cambodia and Thailand (500 BCE-CE 500).” Cambridge Archaeological Journal 25 (2015): 733-57.

Carter, Alison Kyra. "The Production and Exchange of Glass and Stone Beads in Southeast Asia from 500 BCE to the Early Second Millennium CE: An Assessment of the Work of Peter Francis in Light of Recent Research." Archaeological Research in Asia 6 (2016): 16-29.

Carter, Alison Kyra, and Nam C. Kim. "Globalization at the Dawn of History: The Emergence of Global Cultures in the Mekong and Red River Deltas." In The Routledge Handbook of Archaeology and Globalization, edited by Tamar Hodos, 730-50. London: Routledge Taylor \& Francis Group, 2017.

Casile, Anne. 2014. "Changing Religious Landscapes in Gupta Times: Archaeological Evidence from the Area of Badoh-Pathari in Central India." South Asian Studies 30 (2014): 245-68.

Casparis, J. G. de. "Palaeogeography as an Auxiliary Discipline in Research on Early South East Asia." In Early South East Asia: Essays in Archaeology, History, and Historical Geography, edited by R. B. Smith and William Watson, 380-394. New York: Oxford University Press, 1979. 
Castillo, Cristina Cobo, Bérénice Bellina, and Dorian Q. Fuller. "Rice, Beans, and Trade Crops on the Early Maritime Silk Route in Southeast Asia." Antiquity 90 (2016): 1255-69.

Christie, Jan Wisseman. "State Formation in Early Maritime Southeast Asia: A Consideration of the Theories and the Data." Bijdragen tot de Taal-, Land- en Volkenkunde 151 (1995): 235-88.

Cœdès, Georges. "XXV. Deux inscriptions sanskrites du Fou-nan.” Bulletin de l'École française d'Extrême-Orient 31 (1931): 1-12.

Cœdès, Georges. Inscriptions du Cambodge, vol. 2. Hanoi: L’École française d’Extrême-Orient, 1942.

Cœdès, Georges. The Indianised States of Southeast Asia. Translated by Sue Cowing. Honolulu: University of Hawai'i Press, 1968.

Coningham, Robin. "Monks, Caves and Kings: A Reassessment of the Nature of Early Buddhism in Sri Lanka." World Archaeology 27 (1995): 222-42.

Dalsheimer, Nadine, and Pierre-Yves Manguin. "Vișṇu mitrés et réseaux marchands en Asie du Sud-Est: Nouvelles données archéologiques sur le ler millénaire apr. J.-C.” Bulletin de l'École française d'Extrême-Orient 85 (1998): 87-116.

Dao, Linh Côn. "The Oc Eo Burial Group Recently Excavated at Go Thap (Dong Thap Province, Viêt Nam)." In Southeast Asian Archaeology 1994: Proceedings of the 5th International Conference of the European Association of Southeast Asian Archaeologists, vol. 1, edited by Pierre-Yves Manguin, 111-17. Hull: Centre for Southeast Asian Studies, University of Hull, 1998.

Dupont, Pierre. “Les linteaux khmers du VII siecle.” Artibus Asiae 15 (1952): 31-83.

Dupont, Pierre. La statuaire pre-angkorienne. Ascona, Switzerland: Artibus Asiae, 1955.

Dussubieux, Laure, and Bérénice Bellina. "Glass Ornament Production and Trade Polities in the Upper-Thai Peninsula during the Early Iron Age.” Archaeological Research in Asia 13 (2018): 25-36.

Evans, Caitlin, Nigel Chang, and Naho Shimizu. "Sites, Survey, and Ceramics: Settlement Patterns in the First to Ninth Centuries CE in the Upper Mun River Valley, Northeast Thailand." Journal of Southeast Asian Studies 47 (2016): 438-67.

Eyre, Chureekamol Onsuwan. "Social Variation and Dynamics in Metal Age and Protohistoric Central Thailand: A Regional Perspective.” Asian Perspectives 49 (2011): 43-84.

Favereau, Aude, and Bérénice Bellina. "Thai-Malay Peninsula and South China Sea Networks (500 BC-AD 200), Based on a Reappraisal of 'Sa Huynh-Kalanay'-Related Ceramics.” Quaternary International 416 (2016): 219-27.

Fogelin, Lars. An Archaeological History of Indian Buddhism. Oxford: Oxford University Press, 2015.

Furui, R. "Variegated Adaptations: State Formation in Bengal from the Fifth to Seventh Century." In Interrogating Political Systems: Integrative Processes and States in PreModern India, edited by Bhairavi Prasad Sahu and Hermann Kulke, 255-73. New Delhi: Manohar, 2015.

Galloway, Charlotte. "Ways of Seeing a Pyu, Mon and Dvaravati Artistic Continuum." Bulletin of the Indo-Pacific Prehistory Association 30 (2010): 70-8.

Ghosh, Ranjusri. "Pundravardhana in the First Phase of Urbanization (4th Century B.C.-3rd Century A.D.) - A Study." Proceedings of the Indian History Congress 57 (1996): 199-209.

Glover, Ian. "The Dvaravati Gap - Linking Prehistory and History in Early Thailand." Bulletin of the Indo-Pacific Prehistory Association 30 (2010): 79-86.

Glover, Ian C., and Bérénice Bellina. "Ban Don Ta Phet and Khao Sam Kaeo: The Earliest Indian Contacts Re-Assessed." In Early Interactions between South and Southeast Asia: 
Reflections on Cross-Cultural Exchange, edited by Pierre-Yves Manguin, A. Mani, and Geoff Wade, 17-45. Singapore: Institute of Southeast Asian Studies, 2011.

Griffiths, Arlo. "New Documents for the Early History of Punḍravardhana: Copperplate Inscriptions from the Late Gupta and Early Post-Gupta Periods." Pratna Samiksha: A Journal of Archaeology, n. s., 6 (2015): 15-38.

Gupta, Sunil. "The Bay of Bengal Interaction Sphere (1000 BC-AD 500)." Bulletin of the IndoPacific Prehistory Association 25 (2005): 21-30.

Guy, John. "Tamil Merchants and the Hindu-Buddhist Diaspora in Early Southeast Asia." In Early Interactions between South and Southeast Asia: Reflections on Cross-Cultural Exchange, edited by Pierre-Yves Manguin, A. Mani, and Geoff Wade, 243-62. Singapore: Institute for Southeast Asian Studies, 2011.

Ha, Van Tan. “Oc Eo: Endogenous and Exogenous Elements.” Vietnam Social Sciences 1-2 (1986): 91-101.

Hall, Kenneth R. Maritime Trade and State Development in Early Southeast Asia. Sydney: George Allen \& Unwin, 1985.

Havenon, Michael de. "The Earliest Vișṇu Sculpture from Southeast Asia." The Journal of the Walters Art Museum 64/65 (2006/2007): 81-98.

Hawkes, Jason D. "One Size Does Not Fit All: Landscapes of Religious Change in Vindhya Pradesh.” South Asian Studies 30 (2014): 1-15.

Hawkes, Jason D., and Riza Abbas. "Copperplates in Context: A Preliminary Investigation of the Study and Archaeological Settings of Land Grant Inscriptions." Pratnatattva 22 (2016): 41-71.

Heng, Piphal. "Transition to the Pre-Angkorian Period (300-500 CE): Thala Borivat and A Regional Perspective." Journal of Southeast Asian Studies 47 (2016): 484-505.

Hoogervorst, Tom. "If Only Plants Could Talk . . . Reconstructing Pre-Modern Biological Translocations in the Indian Ocean." In The Sea, Identity and History: From the Bay of Bengal to the South China Sea, edited by Satish Chandra and Himanshu Prabha Ray, 67-92. New Delhi: Manohar Press, 2013.

Hoogervorst, Tom. "Tracing Maritime Connections between Island Southeast Asia and the Indian Ocean World." In The Routledge Handbook of Archaeology and Globalization, edited by Tamar Hodos, 751-67. London: Routledge Taylor \& Francis Group, 2017.

Hoogervorst, Tom. "The Role of 'Prakrit' in Maritime Southeast Asia through 101 Etymologies." In Spirits and Ships: Cultural Transfers in Early Monsoon Asia, edited by Andrea Acri, Roger Blench, and Alexandra Landmann, 375-440. Singapore: ISEAS-Yusof Ishak Institute, 2017.

Hudson, Bob. "A Thousand Years before Bagan: Radiocarbon Dates and Myanmar's Ancient Pyu Cities." In Bagan and the World: Early Myanmar and Its Global Connections, edited by Michael Aung-Thwing, John N. Miksic, and Geok Y. Goh, 88-121. Singapore: ISEASYusof Ishak Institute, 2018.

Ikehara-Quebral, Rona M., Miriam T. Stark, William Belcher, Voeun Vuthy, John Krigbaum, R. Alexander Bentley, Michele Toomay Douglas, and Michael Pietrusewsky. "Biocultural Practices during the Transition to History at the Vat Komnou Cemetery, Angkor Borei, Cambodia.” Asian Perspectives 56 (2017): 191-236.

Indrawooth, Phasook. "The Archaeology of the Early Buddhist Kingdoms of Thailand." In Southeast Asia: From Prehistory to History, edited by lan Glover and Peter Bellwood, 120-148. New York: RoutledgeCurzon, 2004. 
Ishizawa, Yoshiaki. “Chinese Chronicles of 1st-5th Century A.D. Funan, Southern Cambodia." In South East Asia \& China: Art, Interaction \& Commerce, Colloquies on Art \& Archaeology in Asia 17, edited by Rosemary Scott and John Guy, 11-31. London: University of London Percival David Foundation of Chinese Art, 1996.

Jacques, Claude. “'Funan', 'Zhenla': The Reality Concealed by these Chinese Views of Indochina." In Early South East Asia: Essays in Archaeology, History and Historical Geography, edited by R. B. Smith and W. Watson (1979), 371-379. Oxford: Oxford University Press.

Jacques, Claude. "Le pays Khmer avant Angkor.” Journal des Savants 1-3 (1986): 59-95. Jacques, Claude. "China and Ancient Khmer History." In South East Asia \& China: Art, Interaction \& Commerce, Colloquies on Art \& Archaeology in Asia 17, edited by Rosemary Scott and John Guy, 32-40. London: Percival David Foundation of Chinese Art, School of Oriental and African Studies, 1995.

Kang, Heejung. "The Spread of Sarnath-Style Buddha Images in Southeast Asia and Shandong, China, by the Sea Route." Kemanusiaan 20 (2013): 39-60.

Kulke, Hermann. "Indian Colonies, Indianization or Cultural Convergence? Reflections on the Changing Image of India's Role in South-East Asia." In Onderzoek in Zuidoost-Azië: Agenda's voor de Jaren Negentig, edited by Henk S. Nordholt, 8-32. Leiden: Rijksuniversiteit te Leiden, Vakgroep Talen en Culturen van Zuidoost-Azië en Oceanië, 1990.

Lankton, James. W., and Laure Dussubieux. "Early Glass in Asian Maritime Trade: A Review and an Interpretation of Compositional Analyses." Journal of Glass Studies 48 (2006): 121-44.

Lavy, Paul. A. "As in Heaven, So on Earth: The Politics of Vișṇu, Śiva and Harihara Images in Preangkorian Khmer Civilisation.” Journal of Southeast Asian Studies 341 (2003): 21-39. Lavy, Paul. A. "Conch-on-Hip Images in Peninsular Thailand and Early Vaișṇava Sculpture in Southeast Asia." In Before Siam: Essays in Art and Archaeology, edited by Nicolas Revire and Stephen A. Murphy (2014), 152-173. Bangkok: River Books.

Le Thi Lien. "Gold Plaques and Their Cultural Contexts in the Oc Eo Culture." Bulletin of the Indo-Pacific Prehistory Association 25 (2005): 145-54.

Le Thi Lien. "Hindu Deities in Southern Vietnam: Images on Small Archaeological Artefacts." In Early Interactions between South and Southeast Asia: Reflections on Cross-Cultural Exchange, edited by Pierre-Yves Manguin, A. Mani, and Geoff Wade, 407-431. Singapore: Institute for Southeast Asian Studies, 2011.

Le Thi Lien. "Brahmi Inscriptions from Archaeological Sites in Southern Vietnam During the 1st Millennium CE." In Advancing Southeast Asian Archaeology 2013: Selected Papers from the First SEAMEO SPAFA International Conference on Southeast Asian Archaeology, Chonburi, Thailand 2013, 362-71. Bangkok: SEAMEO SPAFA Regional Centre for Archaeology and Fine Arts, 2015.

Mabbett, I. W. "The Indianization of Mainland Southeast Asia: A Reappraisal." In Living a Life in Accord with Dhamma: Papers in Honor of Professor Jean Boisselier on his Eightieth Birthday, edited by Natasha Eilenberg, M. C. Subhadradis Diskul, and Robert L. Brown, 42-55. Bangkok: Silpakorn University, 1997.

Malleret, L. L'Archéologie du Delta du Mekong. Paris: Publication de l'École française d'Extrême-Orient, 1959-1963. 
Manguin, Pierre-Yves. "Trading Ships of the South China Sea. Shipbuilding Techniques and Their Role in the History of the Development of Asian Trade Networks." Journal of the Economic and Social History of the Orient 36 (1993): 253-80.

Manguin, Pierre-Yves. "City-States and City-State Cultures in Pre-15th-Century Southeast Asia." In A Comparative Study of Thirty City-State Cultures, edited by Mogens Herman Hansen, 409-16. Copenhagen: Royal Danish Academy of Science and Letters, 2000. Manguin, Pierre-Yves. "The Archaeology of Early Maritime Polities of Southeast Asia." In Southeast Asia: From Prehistory to History, edited by lan Glover and Peter Bellwood, 282-313. New York: RoutledgeCurzon, 2004.

Manguin, Pierre-Yves. "Pan-Regional Responses to South Asian Inputs in Early Southeast Asia." In 50 Years of Archaeology in Southeast Asia: Essays in Honour of lan Glover, edited by Bérénice Bellina, Elisabeth A. Bacus, Thomas O. Pryce, and Jan Wisseman Christie, 170-82. Bangkok: River Books, 2010.

Manguin, Pierre-Yves. "Introduction." In Early Interactions between South and Southeast Asia: Reflections on Cross-Cultural Exchange, edited by Pierre-Yves Manguin, A. Mani, and Geoff Wade, xiii-xxxi. Singapore: Institute for Southeast Asian Studies, 2011.

Manguin, Pierre-Yves. "Ships and Shipping in Southeast Asia." Oxford Research Encyclopedia of Asian History, edited by David Ludden, 2017. doi: 10.1093/acrefore/ 9780190277727.013.30.

Manguin, Pierre-Yves. "The Transmission of Vaișnavism across the Bay of Bengal: Trade Networks and State Formation in Early Historic Southeast Asia." In Early Global Interconnectivity across the Indian Ocean World. Vol. 2, Exchange of Ideas, Religions, and Technologies, edited by Anglea Schottenhammer, 51-68. Basingstoke, UK: Palgrave Macmillan, 2019.

Manguin, Pierre-Yves, and Vo Si Khai. "Excavations at the Ba The/Oc Eo Complex (Viet Nam): A Preliminary Report on the 1998 Campaign." In Southeast Asian Archaeology 1998: Proceedings of the 7th International Conference of the European Association of Southeast Asian Archaeologists, edited by Wibke Lobo and Stefanie Reimann, 107-21. Hull: Centre for South-East Asian Studies, University of Hull, 2000.

Murphy, Stephen A. "The Case for Proto-Dvāravatī: A Review of the Art Historical and Archaeological Evidence.” Journal of Southeast Asian Studies 47 (2016): 366-92.

Murphy, Stephen A., and Miriam T. Stark. "Introduction: Transition from Late Prehistory to Early Historic Periods in Mainland Southeast Asia c. Early to Mid-First Millennium CE." Journal of Southeast Asian Studies 47 (2016): 333-40.

Neelis, Jason Emmanuel. Early Buddhist Transmission and Trade: Networks Mobility and Exchange within and beyond the Northwestern Borderlands of South Asia. Leiden: Brill, 2011.

Nishimura, Masanari, Nguyễn Duy Tỷ, and Huỳnh Đình Chung. "Excavation of Nhơn Thành at the Hậu Giang River Reach, Southern Vietnam.” Taida Journal of Art History 25 (2009): $1-68$.

O'Connor, Stanley J. Hindu Gods of Peninsular Siam. Supplementum 28. Ascona, Switzerland: Artibus Asiae, 1972.

O’Connor, Stanley J. “Some Early Siva Lingas in Nakorn Si Thammarat, Peninsular Thailand." Journal of the Siam Society 71 (1983): 1-5.

Pal, Sayantani. "Gupta Rule in Bengal.” Proceedings of the Indian History Congress, 69th Session, Kannur 2008, 79-85. Kolkata: Indian History Congress, 2009.

Pelliot, Paul. “Le Fou-Nan.” Bulletin de l'École française d'Extrême-Orient 3 (1903): 248-303. 
Pietrusewsky, Michael, and Rona M. Ikehara-Quebral. "The Bioarchaeology of the Vat Komnou cemetery, Angkor Borei, Cambodia.” Bulletin of the Indo-Pacific Prehistory Association 26 (2006): 86-97.

Pou, Saveros. "Āśrama dans l'Ancien Cambodge." Journal Asiatique 290 (2002): 315-39.

Ray, Himanshu Prabha. Monastery and Guild: Commerce under the Satavahanas. Delhi: Oxford University Press, 1986.

Ray, Himanshu Prabha. "Early Maritime Contacts between South and Southeast Asia." Journal of Southeast Asian Studies 20 (1989): 42-54.

Ray, Himanshu Prabha. The Winds of Change: Buddhism and the Maritime Links of Early South Asia (New Delhi: Oxford University Press, 1994)

Ray, Himanshu Prabha. "The Apsidal Shrine in Early Hinduism: Origins, Cultic Affiliation, Patronage.” World Archaeology 36 (2004): 343-359.

Ray, Himanshu Prabha. "The Archaeology of Bengal: Trading Networks, Cultural Identities." Journal of the Social and Economic History of the Orient 49 (2006): 68-95.

Ray, Himanshu Prabha. "Multi-Religious Maritime Linkages across the Bay of Bengal during the First Millennium CE." In Before Siam: Essays in Art and Archaeology, edited by Nicolas Revire and Stephen A. Murphy, 135-51. Bangkok: River Books, 2014.

Ray, Himanshu Prabha. Archaeology and Buddhism in South Asia. Oxfordshire, UK: Taylor and Francis, 2017.

Revire, Nicolas. "New Perspectives on the Origin and Spread of Bhadrasāna Buddhas throughout Southeast Asia (7th-8th Centuries CE)." In Connecting Empires and States: Selected Papers from the 13th International Conference of the European Association of Southeast Asian Archaeologists, edited by Mai Lin Tjoa-Bonatz, Andreas Reinecke, and Dominik Bonatz, 127-43. Singapore: NUS Press Pte Ltd, 2012.

Revire, Nicolas. "Dvāravatī and Zhenla in the Seventh to Eighth Centuries: A Transregional Ritual Complex." Journal of Southeast Asian Studies 47 (2016): 393-417.

Revire, Nicolas. "From Gandhara to Java: A Comparative Study of Bhadrasana Buddhas and their Related Bodhisattva Attendants in South and Southeast Asia," in India and Southeast Asia: Cultural Discourses, edited by Anna L. Dallapiccola, 280-304. Mumbai: K.R. Cama Cultural Institute, 2017.

Reza, Mohammad Habib, Soumyen Bandyopadhyay, and Azizul Mowla. "Traces of Buddhist Architecture in Gupta and Post-Gupta Bengal: Evidence from Inscriptions and Literature." Journal of Eurasian Studies 7 (2015): 9-19.

Sanderson, David C. W., Paul Bishop, Miriam T. Stark, and Joel Q. Spencer. “Luminescence Dating of Anthropogenically Reset Canal Sediments from Angkor Borei, Mekong Delta, Cambodia." Quaternary Science Reviews 22 (2003): 1111-1121.

Schopen, Gregory. “On Monks, Nuns, and 'Vulgar Practices': The Introduction of the Image Cult into Indian Buddhism.” Artibus Asiae 49 (1988-1989): 153-168

Shaw, Julia. "Nāga Sculptures in Sanchi’s Archaeological Landscape: Buddhism, Vaișṇavism, and Local Agricultural Cults in Central India, First Century BCE to Fifth Century CE." Artibus Asiae 64 (2004): 5-59.

Shaw, Julia. "Monasteries, Monasticism, and Patronage in Ancient India: Mawasa, a Recently Documented Hilltop Buddhist Complex in the Sanchi Area of Madhya Pradesh." South Asian Studies 27 (2011): 111-30.

Shaw, Julia. "Archaeologies of Buddhist Propagation in Ancient India: 'Ritual' and 'Practical' Models of Religious Change.” World Archaeology 45 (2013): 83-108. 
Singh, Upinder. "Cults and Shrines in Early Historical Mathura (c. 200 BC-AD 200)." World Archaeology 36 (2004): 378-98.

Skilling, Peter. "Buddhism and the Circulation of Ritual in Early Peninsular Southeast Asia." In Early Interactions between South and Southeast Asia: Reflections on Cross-Cultural Exchange, edited by Pierre-Yves Manguin, A. Mani, and Geoff Wade, 371-84. Singapore: Institute for Southeast Asian Studies, 2011.

Ślączka, Anna Aleksandra. "The Depositing of the Embryo: Temple Consecration Rituals in the Hindu Tradition of South and Southeast Asia: A Study of the Textual and Archaeological Evidence." In Early Interactions between South and Southeast Asia: Reflections on CrossCultural Exchange, edited by Pierre-Yves Manguin, A. Mani, and Geoff Wade, 433-42. Singapore: Institute for Southeast Asian Studies, 2011.

Ślączka, Anna Aleksandra. "The Brick Structures of Go Thap: Tombs or Temples?" Bulletin of the Indo-Pacific Prehistory Association 31 (2011): 109-117.

Stargardt, Janice. The Ancient Pyu of Burma. Vol. 1, Early Pyu Cities in a Man-Made Landscape. Cambridge: Publications on Ancient Civilizations in Southeast Asia; Singapore: Institute of Southeast Asian Studies, 1990.

Stargardt, Janice. "Death Rituals of the Late Iron Age and Early Buddhism in Central Burma and South-East India - Whose Norms, Whose Practices?" In Im Dickicht der Gebote: Studien zur Dialektik von Norm und Praxis in der Buddhismusgeschichte Asiens, Historia Religionum 26, edited by Peter Schalk, 407-33. Uppsala: Acta Universitatis Upsaliensis, 2005.

Stargardt, Janice. "From the Iron Age to Early Cities at Sri Ksetra and Beikthano, Myanmar." Journal of Southeast Asian Studies 47 (2016): 341-65.

Stark, Miriam T. "The Transition to History in the Mekong Delta: A View from Cambodia." International Journal of Historical Archaeology 2 (1998): 175-204.

Stark, Miriam T. “Pre-Angkor Earthenware: Ceramics from Cambodia's Mekong Delta," Udaya: Journal of Khmer Studies 1 (2000): 69-89.

Stark, Miriam T. “Angkor Borei and the Archaeology of Cambodia's Mekong Delta.” In Art \& Archaeology of Fu Nan: Pre-Khmer Kingdom of the Lower Mekong Valley, edited by J. Khoo, 87-106. Bangkok: Orchid Books, 2003.

Stark, Miriam T. "Early Mainland Southeast Asian Landscapes in the First Millennium AD." Annual Review of Anthropology 35 (2006): 407-32.

Stark, Miriam T. "Pre-Angkorian Settlement Trends in Cambodia's Mekong Delta and the Lower Mekong Archaeological Project." Bulletin of the Indo-Pacific Prehistory Association 26 (2006): 98-109.

Stark, Miriam T. "Inscribing Legitimacy and Building Power in the Mekong Delta." In Counternarratives and Macrohistories: New Agendas in Archaeology and Ancient History, edited by Geoffrey Emberling, 75-105. New York: Cambridge University Press, 2015.

Stark, Miriam T., and S. Jane Allen. "The Transition to History in Southeast Asia: An Introduction." International Journal of Historical Archaeology 2 (1998): 163-75.

Stark, Miriam T., and Bong Sovath. "Recent Research on the Emergence of Early Historic States in Cambodia's Lower Mekong." Bulletin of the Indo-Pacific Prehistory Association 19 (2001): 85-98.

Stark, Miriam T., and Shawn Fehrenbach. "Earthenware Ceramic Technologies of Angkor Borei, Cambodia.” Udaya, Journal of Khmer Studies 14 (2019): 109-133. 
Stark, Miriam T., P. Bion Griffin, Chuch Phoeurn, Judy Ledgerwood, Michael Dega, Carol Mortland, Nancy Dowling, James M. Bayman, Bong Sovath, Tea Van, Chhan Chamroeun, and Kyle Latinis. "Results of the 1995-1996 Archaeological Field Investigations at Angkor Borei, Cambodia." Asian Perspectives 38 (1999): 7-36.

Stark, Miriam T., David C. W. Sanderson, and Rob G. Bingham. "Monumentality in the Mekong Delta: Luminescence Dating and Implications." Bulletin of the Indo-Pacific Prehistory Association 26 (2006): 110-20.

Strauch, Ingo. "The Character Writing System Between Identity and Assimilation." In The Idea of Writing: Writing across Borders, edited by Alex de Voogt and Joachim Friedrich Quack, 131-68. Leiden: Brill, 2011.

Trinh Thi Hòa. “Réflexions sur les vestiges de la culture d’Óc Eo.” Etudes Vietnamiennes, n. s., 50 (1996): 111-23.

Vickery, Michael. Society, Economics, and Politics in Pre-Angkor Cambodia: The 7th-8th Centuries. Tokyo: The Centre for East Asian Cultural Studies for Unesco, 1998.

Wheatley, Paul. "Presidential Address: India Beyond the Ganges - Desultory Reflections on the Origins of Civilization in Southeast Asia." Journal of Asian Studies 42 (1982): 13-28.

Wheatley, Paul. "The Malay Peninsula as Known to the Chinese of the Third Century A.D." Journal of the Malayan Branch of the Royal Asiatic Society 28 (1955): 1-23.

Wheatley, Paul. The Golden Khersonese: Studies in the Historical Geography of the Malay Peninsula before A.D. 1500. Kuala Lumpur: University of Malaya Press, 1961.

Wheatley, Paul. Nāgara and Commandery: Origins of the Southeast Asian Urban Traditions. Research Paper 207-208. Chicago: Department of Geography, University of Chicago, 1983.

White, Joyce C. "Incorporating Heterarchy into Theory on Socio-Political Development: The Case from Southeast Asia." In Heterarchy and the Analysis of Complex Societies, Archeological Papers of the American Anthropological Association 6, edited by Robert M. Ehrenreich, Carole L. Crumley, and Janet E. Levy, 101-123. Arlington, VA: American Anthropological Association, 1995.

Wicks, R. S. Money, Markets, and Trade in Early Southeast Asia: The Development of Indigenous Monetary Systems to AD 1400. Ithaca, NY: Southeast Asia Program, Cornell University, 1992.

Willis, Michael. "The Formation of Temple Ritual in the Gupta Period: pūjā and pañcamahāyajña." In Prajñādhara: Essays on Asian Art, History, Epigraphy and Culture in Honour of Gouriswar Bhattacharya, edited by Arundhati Banerji and Gerd J. R. Mevissen, 66-88. New Delhi: Kaveri Books, 2009.

Wolters, Oliver W. History, Culture and Region in Southeast Asian Perspectives. Ithaca, NY: Southeast Asian Program, Cornell University, 1999. 